\title{
الأحاديث المرفوعة الواردة في لقمان دراسة موضوعية
}

\author{
الدكتور

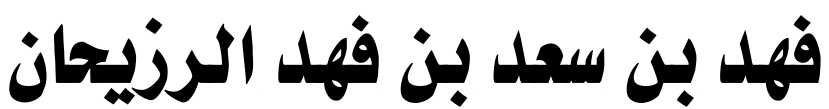 \\ الاستاذ المساعد - قسم أصول الدين \\ في كلية الشريعة والدراسات الإسلامية بالأحساء \\ جامعة الإمام محمل بن سعود الإسلامية - المملكة العربية السعودية
}




$$
\begin{aligned}
& \text { الأحاديث المرفوعة الواردة في لقمان } \\
& \text { دراسة موضوعية ، والية } \\
& \text { الدكتور/ فهد بن سعد بن فهد الرزيحان } \\
& \text { الاستاذ المساعد - قسم أصول الدين } \\
& \text { في كلية الشريعة والدراسات الإسامية بالأحساء }
\end{aligned}
$$

جامعة الإمام محمد بن سعود الإسلامية - المملكة العربية السعودية

Abstract: Hadiths raised in Luqman

Action : fahad saad fahad alruzayhan

Faculty of Theology - Assistant Professor

College of sharia and islamic studies in al-ahsaa

Imam mohammad ibn saud islamic university

Kingdom of Saudi Arabia 


\section{ملخص البحث}

موضوع البحث الأحاديث المرفوعة الواردة في لقمان ، ويهدف البحت

هذا البحث بدراسة الأحاديث المرفوعة في لقحان وتناول المسائل التي

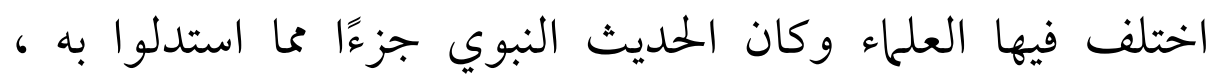

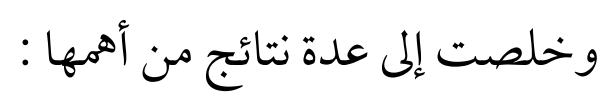

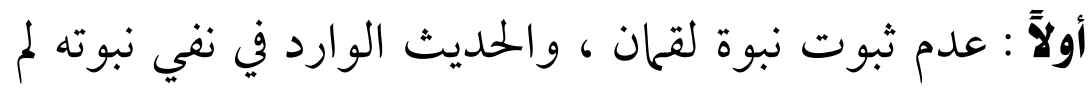

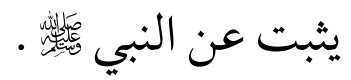

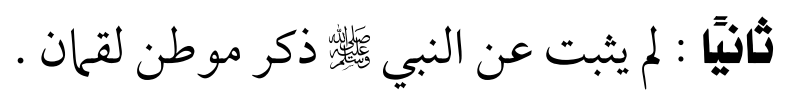

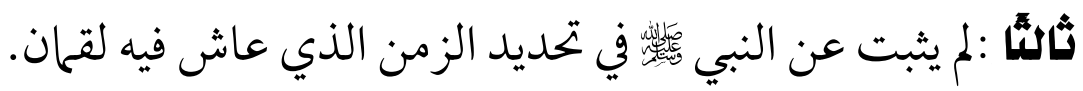

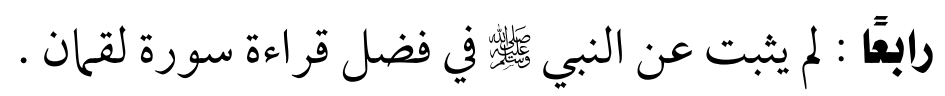

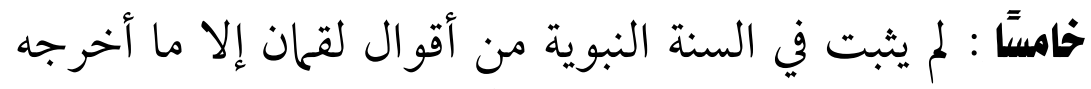

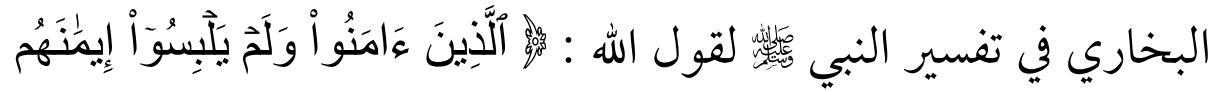

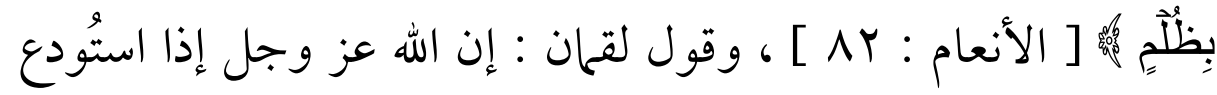
شئًا حفظه . 


$$
\text { بسم الله الرحمن الرحيم }
$$

\section{المقدمة}

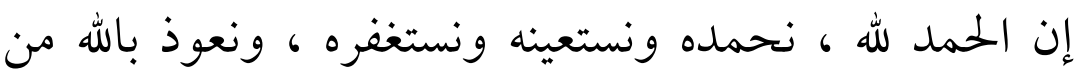

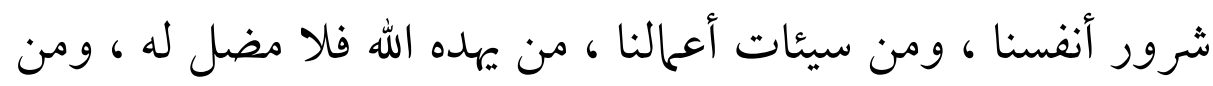

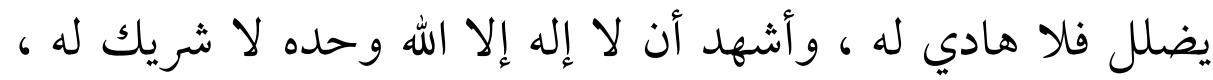

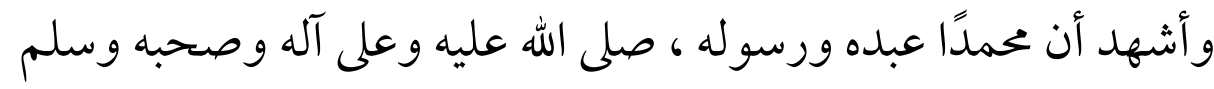

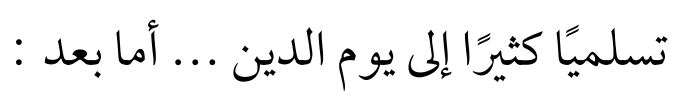

فقد ذكر الله عز وجل في كتابه وصايا لقمان الحكيم لابنه لنتأملها

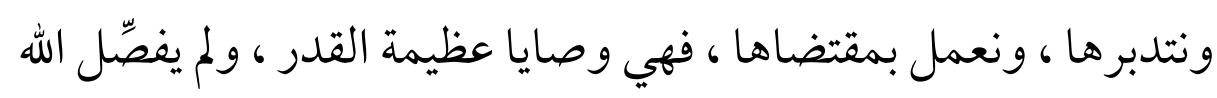

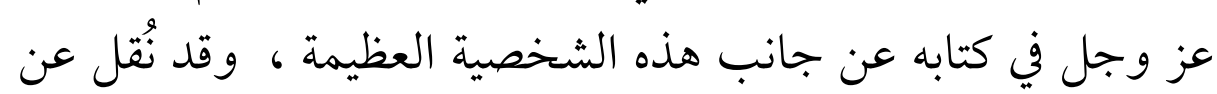

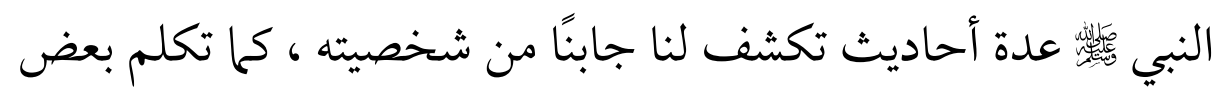
العلماء في تفاصيلها ، وقد رغبت في دراسة جوانب هذه الشخصية

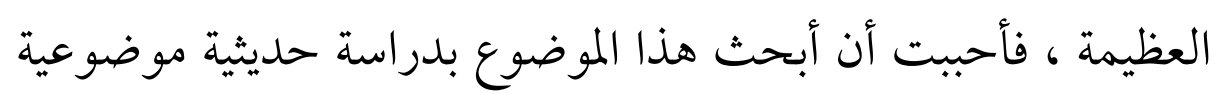

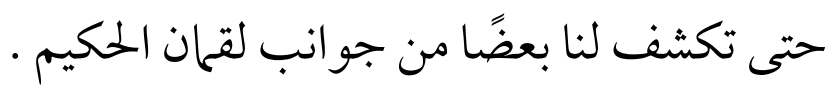

\section{أهمية الموضوع وأسباب اختياره :}

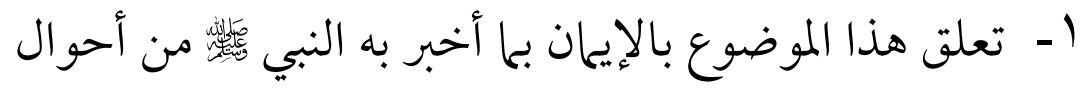

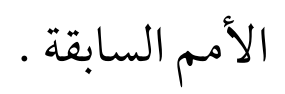

Y- عدم وجود بحث استقصى الأحاديث المرفوعة الواردة في

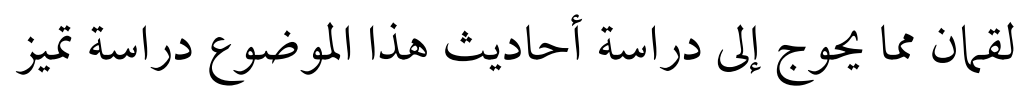

$$
\text { الثابت من غيره . }
$$




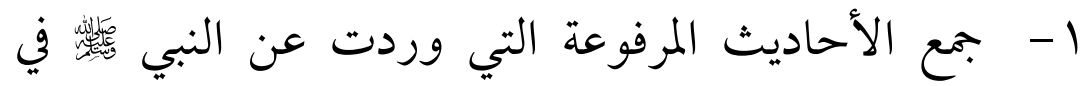

$$
\text { لقحان . }
$$

r- تخريج الأحاديث الواردة في هذا الموضوع ، ودراسة

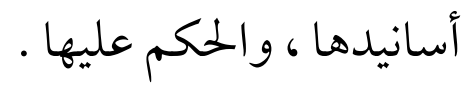

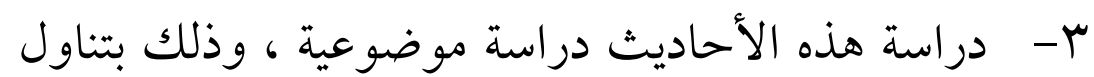

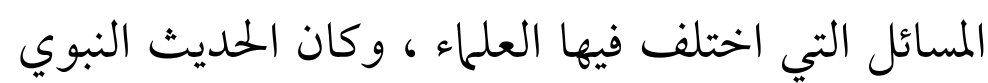

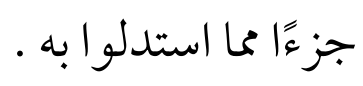

حلدود البحث : حزئ

أقصد في هذا البحث جمع الأحاديث المرفوعة التي وردت في

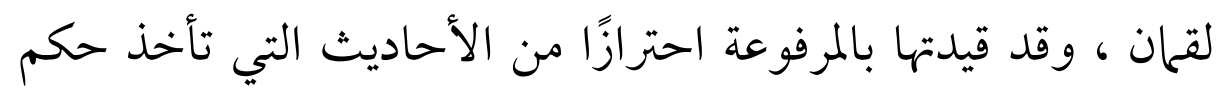

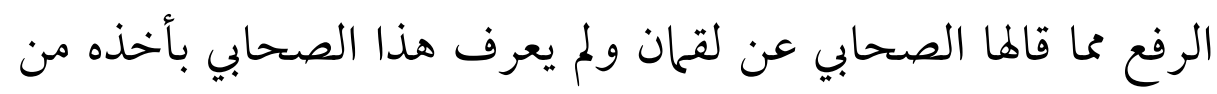

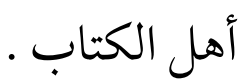

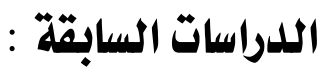

لم أقف بعد البحث والتحري على دراسة حديثية متعلقة

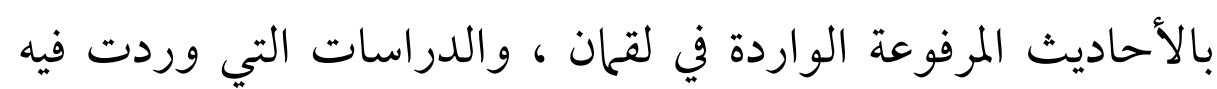

$$
\text { دراسات تربوية ووعظية وليست حديثية . }
$$

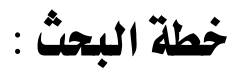

تشتمل خطة البحث على مقدمة ، وتمهيد ، وأربعة مباحث ،

وخاتمة ، وفهارس ، وتفصيل ذلك على النحو الآتي : 
(091)

$$
\text { التههيل : ترجمة غختصرة عن لقحان . }
$$

المبحث الأول: الحديث المرفوع الوارد في نبوة لقحان ، و فيه مطلبان:

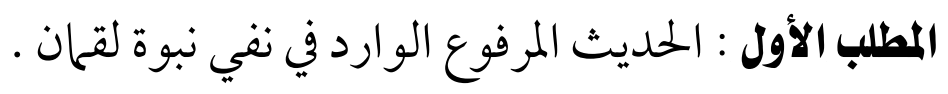

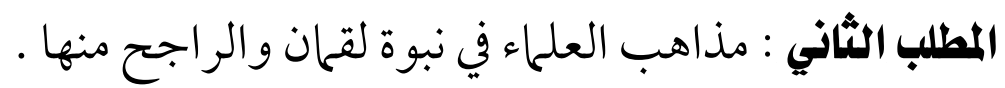
المبحث الثاني : موطن لقمان ، وفيه مطلبان :

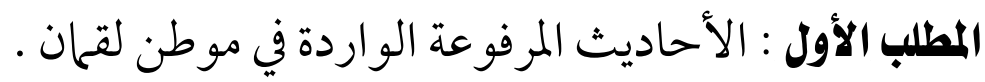

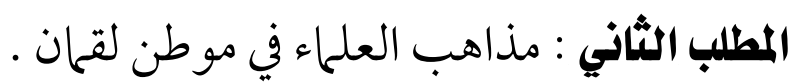

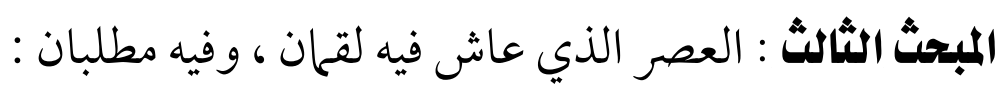

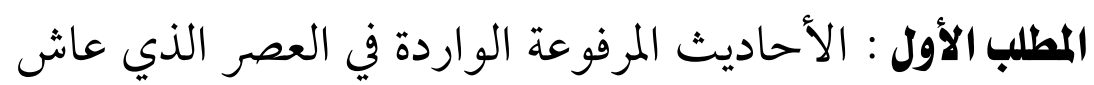
فيه لقحان .

المطلب الثاني : تحديد العصر الذي عاش فيه لقحان . المبحث الرابع : شفاعته يوم القيامة للمسلمين .

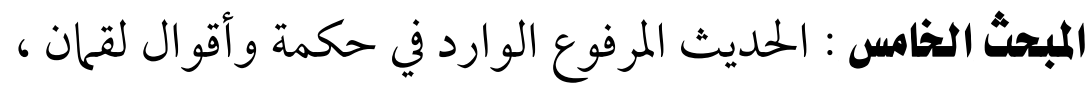
وفيه مطلبان :

المطلب الأول : الحديث المرفوع الوارد في حكمة لقحان .

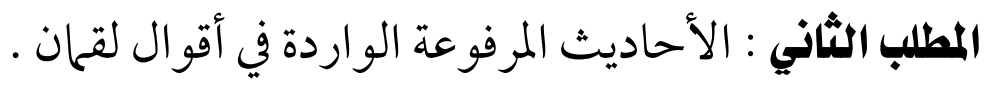

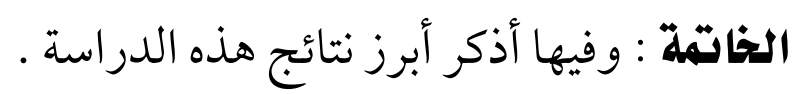

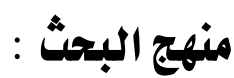

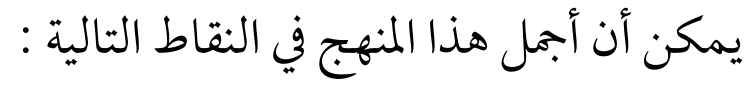

أولاً : منهج تخريج الأحاديث ، ودراسة أسانيدها ، والحكم عليها : 
1- أكتفي في تخريج أحاديث الصحيحين بها إلا لزيادة مؤثرة في

$$
\text { r- أتوسع في تخريج أحاديث غير الصحيحين . }
$$

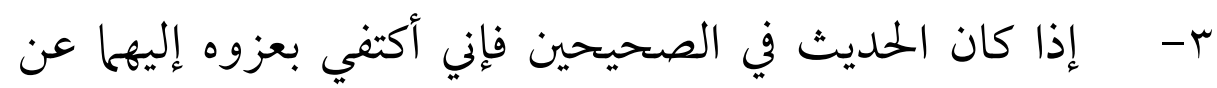

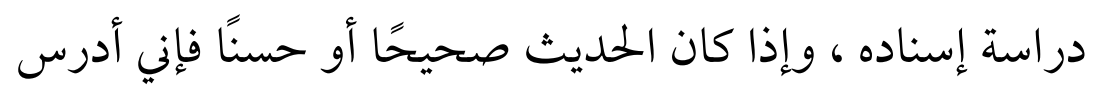

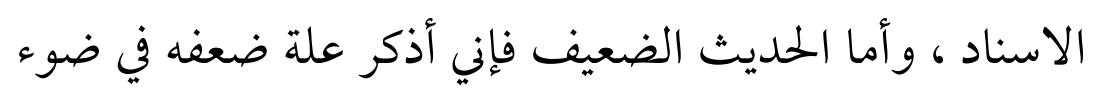
أقوال العلماء مع الترجيح والتعليل .

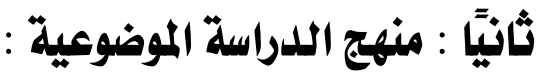

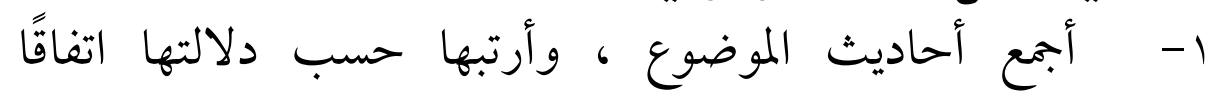

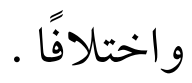

r - أعتني بخدمة المتن و التعليق عليه وتحريره وضبط مشكله .

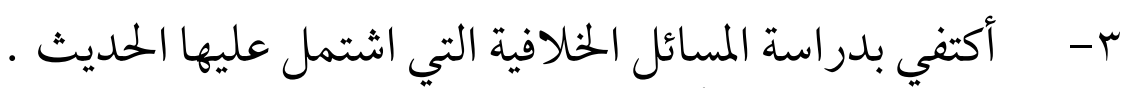

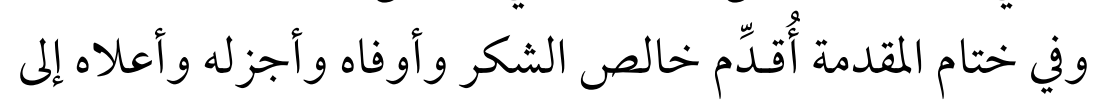

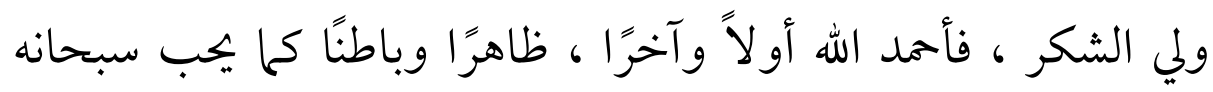

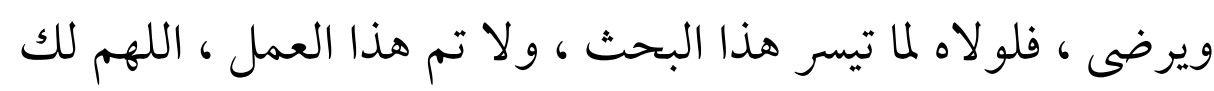

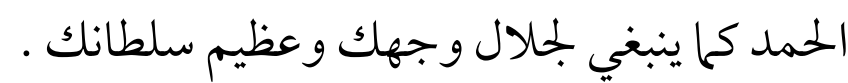

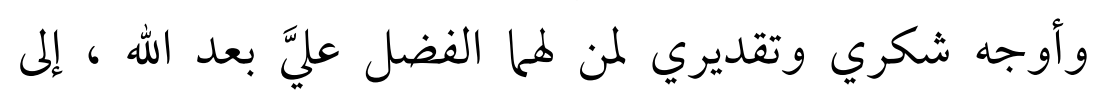

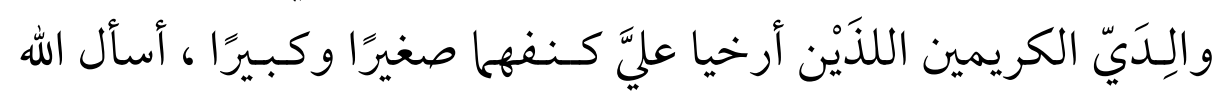
أن يجزيهها خير الجزاء ، وأن يطيل في أعلارهما على الطاعة والصحة الصحئ و السلامة . 
وأوجه شكري الجزيل ، وعرفاني الكبير لولاة أمرنا في بلادنا

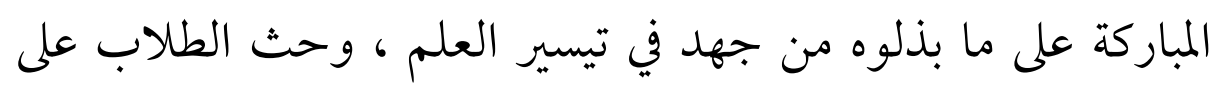

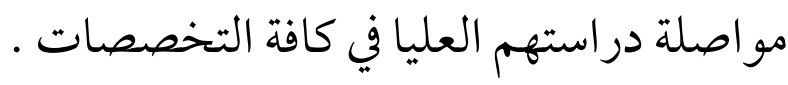

أسال الله أن يجعل عملي هذا كله خالصًا لو جهه الكريم ، وصلى فيلى

الله وسلم على نبينا محمد ، وعلى آله وصحبه أجمعين . 


\section{التمهيد : ترجمة مختصرة عن لقمان .}

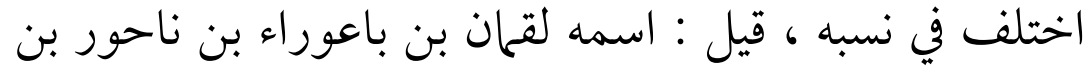

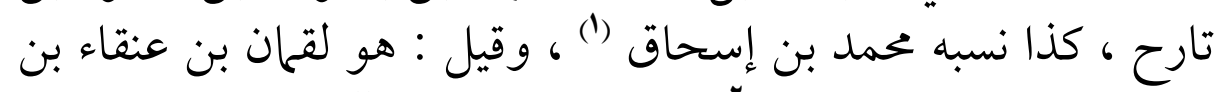

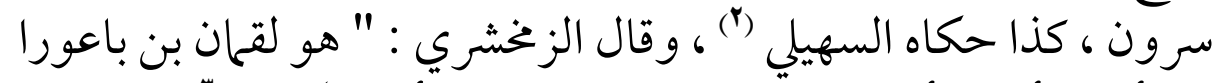

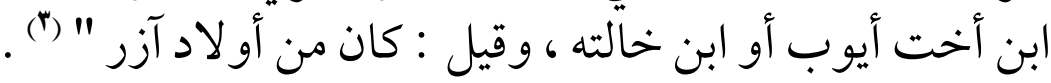

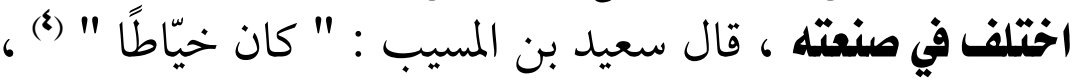

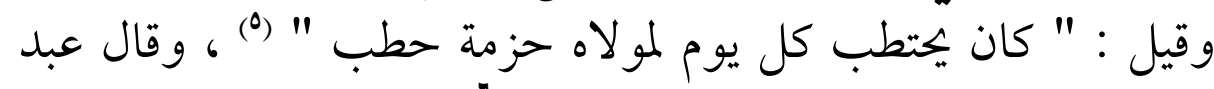

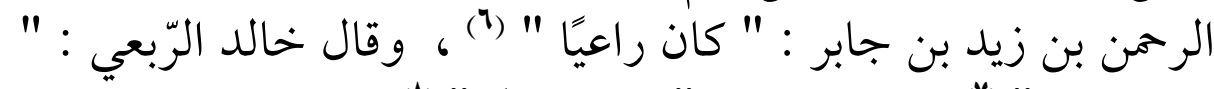

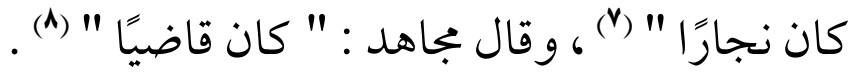

1 - انظر : قصص الأنبياء ، لأبي إسحاق أحمد بن محمد بن إبراهيم النيسابوري الثعلبي

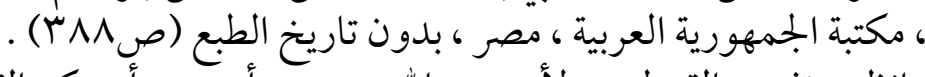

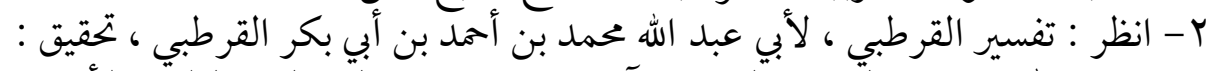

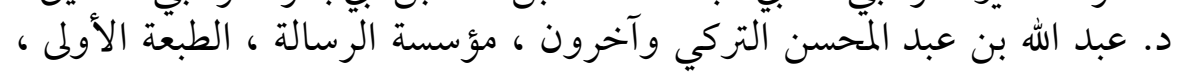
(

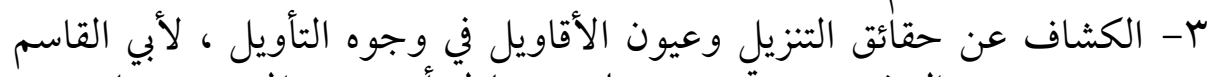

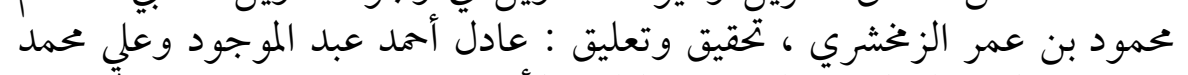

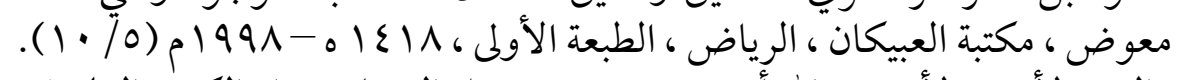

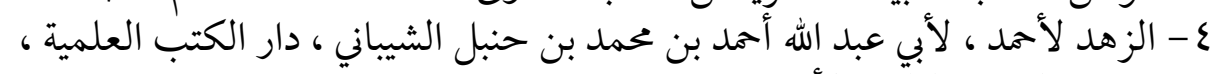

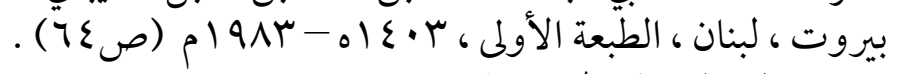

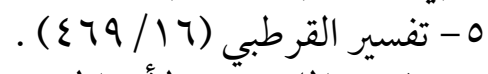

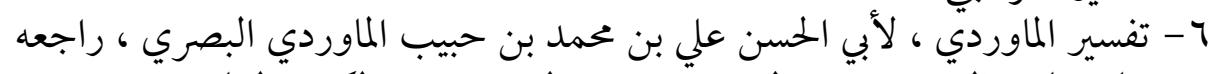

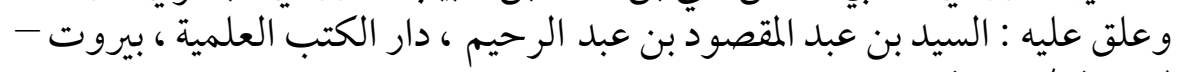

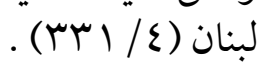

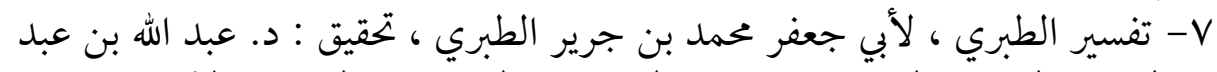

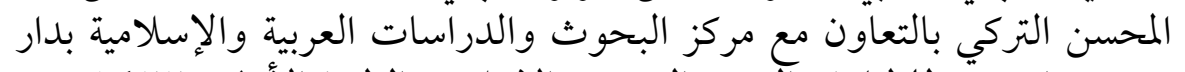

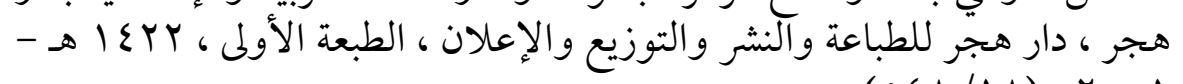

$$
\begin{aligned}
& \text {. الزهد } \\
& \text { 1- الزهد لأمد (صعار) ) . }
\end{aligned}
$$


(090)

واختلف في اسم ابن لقحان الذي حكى الله في كتابه

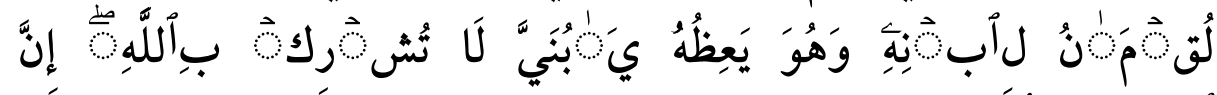

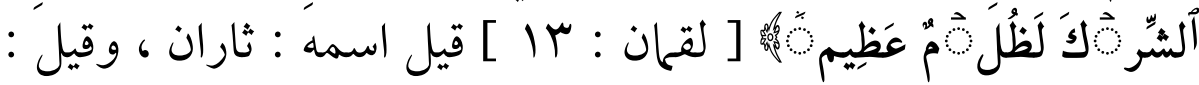

اسمه مشكم ، وقيل : اسمه أنعم ، وقيل : اسمه ماتان (1) .

أما العصر الذي عاش فيه ، و الكلام على نبوته سيأتي بإذن الله .

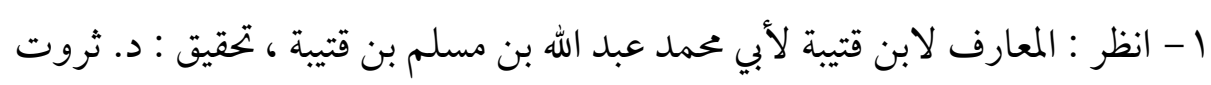

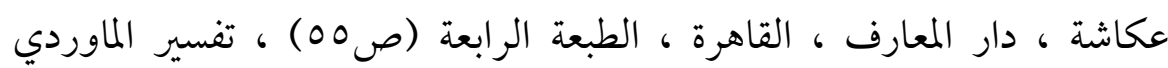

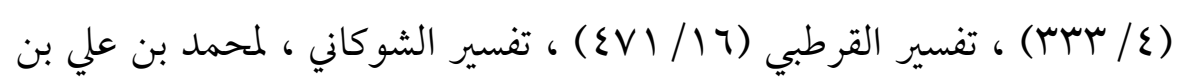

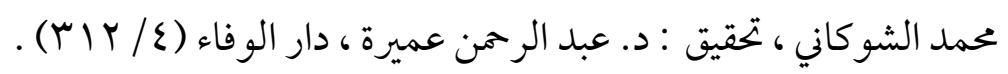




\section{المبحث الأول : الحديث المرفوع الوارد في نبوة لقماز ، وفيه مطلبان :

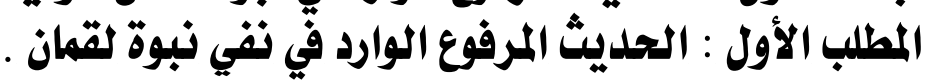

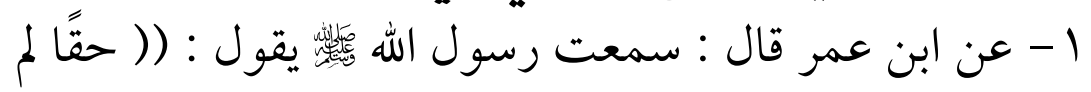

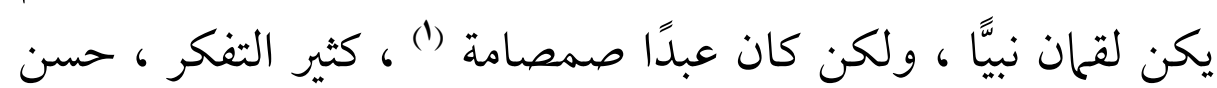

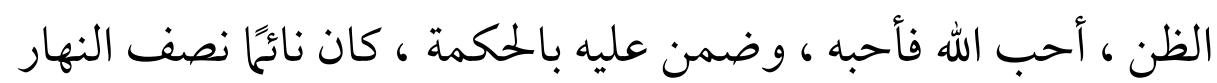

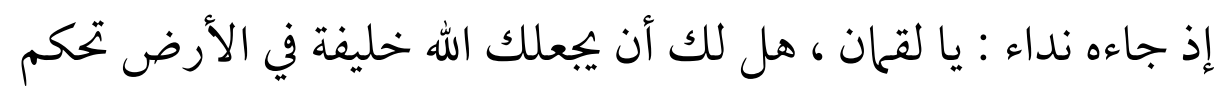

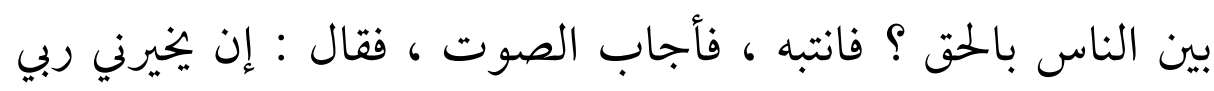

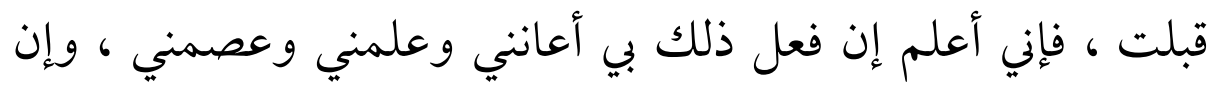

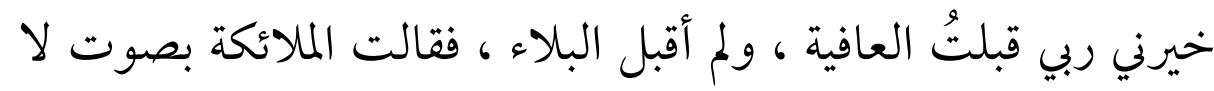

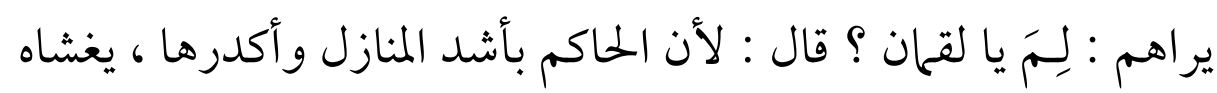
الظلم من كل مكان ، ينجو ويُعان ، وبالحري أن ينجو و إن أخطاً أخطاً

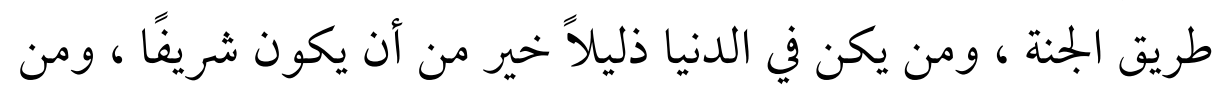

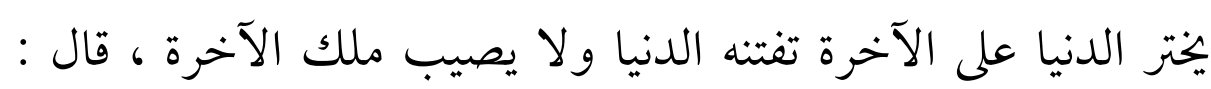

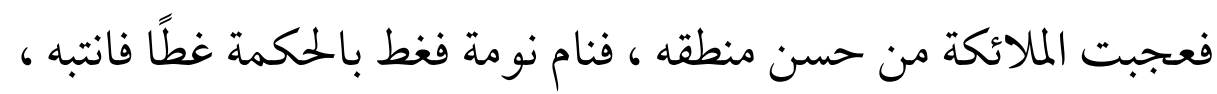

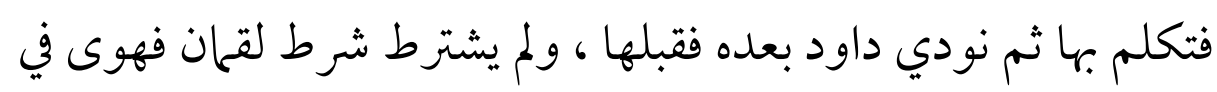

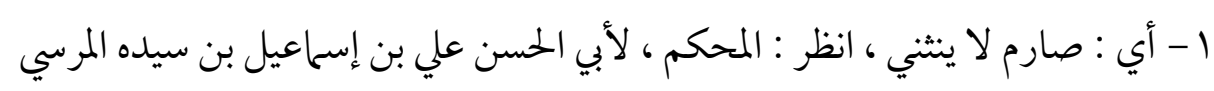

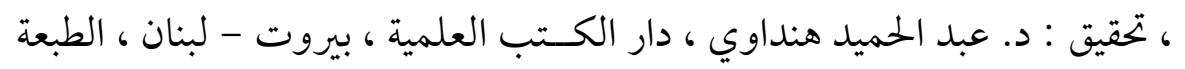

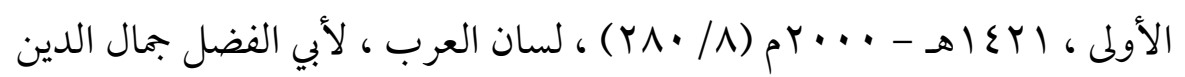

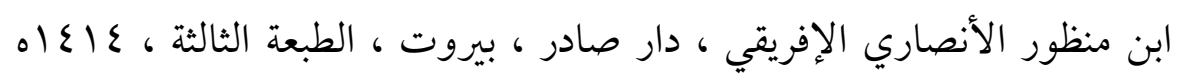
. (r $(r V / T)$ 
(०9V)

الخطيئة غير مرة ، وكل ذلك يصفح الله ويتجاوز ويغفر له ، وكان لقحان

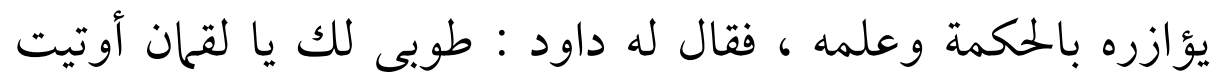

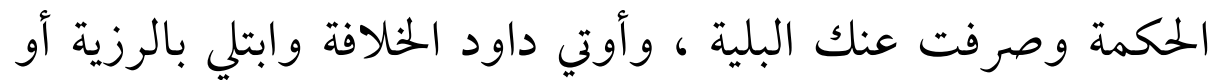

الفتنة ()) . الفنا

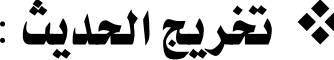

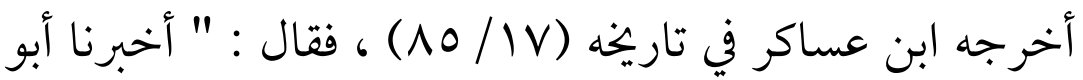

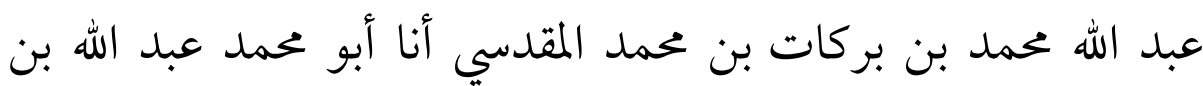

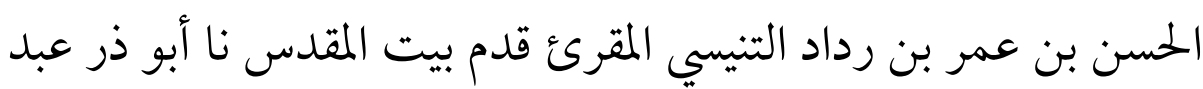

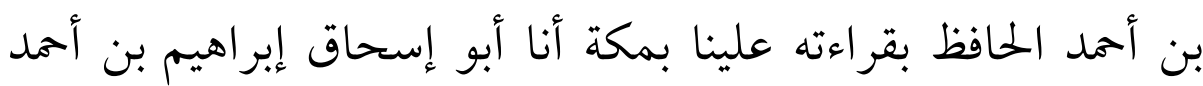

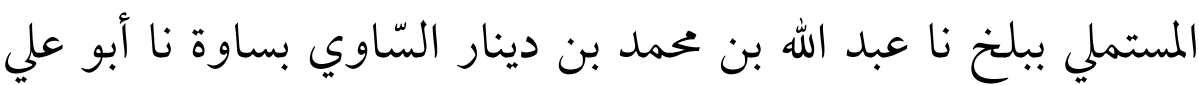

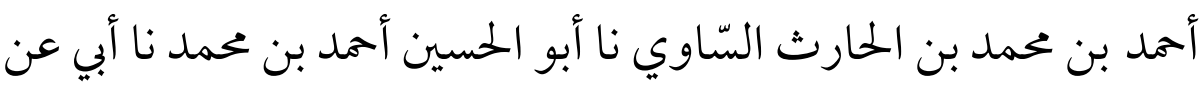

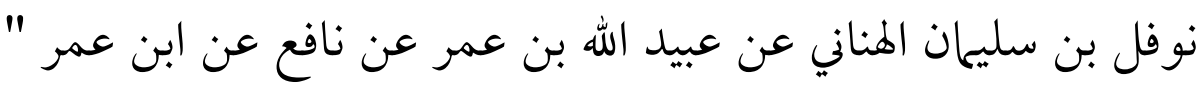

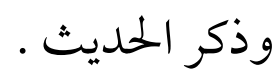

\section{: الحكم على اسناد الحلديث}

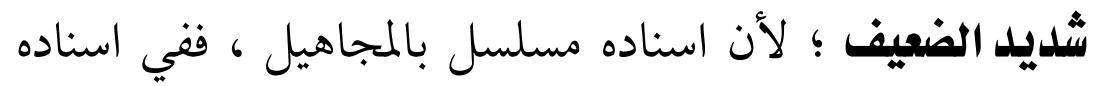
عبد الله بن الحسن بن عمر بن رداد التنيسي وعبد الله بن محمد بن دينار

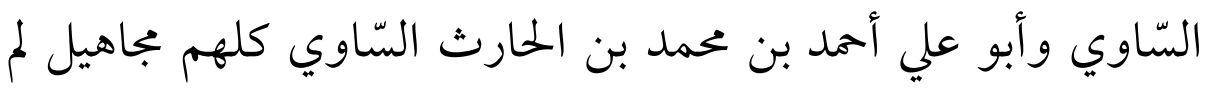

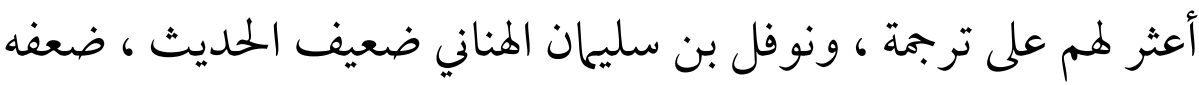


أبو حاتم (') ، والدارقطني (") ، وقال ابن عدي : " ويحدث محمد بن نوفل هذا بأحاديث غير محفوظة ، ويشبه أن يكون ضعيفًا " (") ، وقال همال

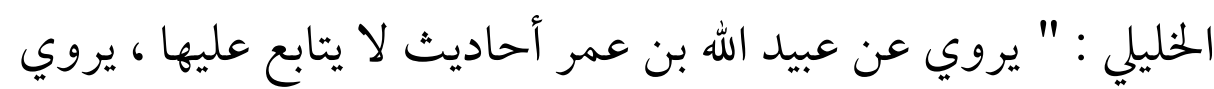

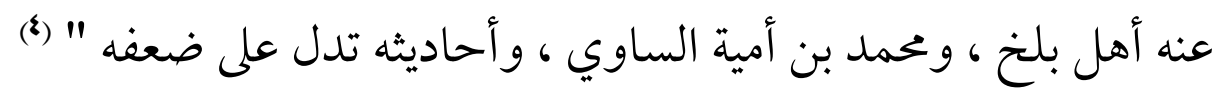
. ....

1 - الجرح والتعديل ، لأبي محمد عبد الرحمن الر ازي ابن أبي حاتم ، اعتنى بتصحيحه

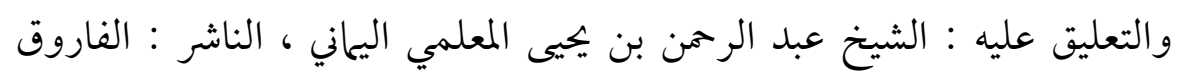

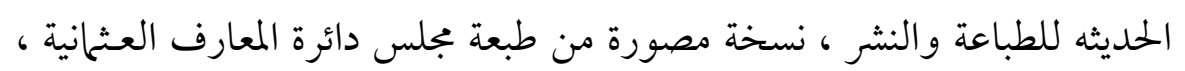

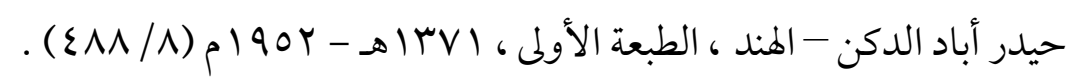

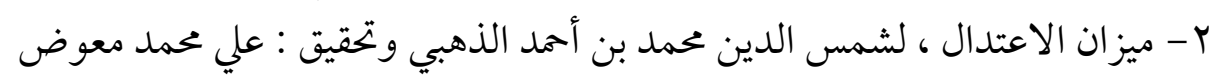

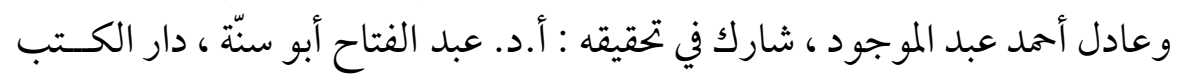

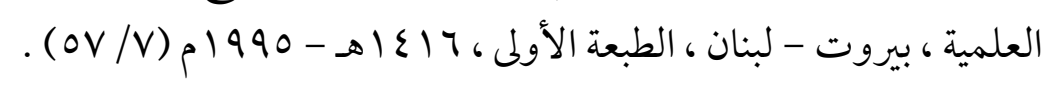

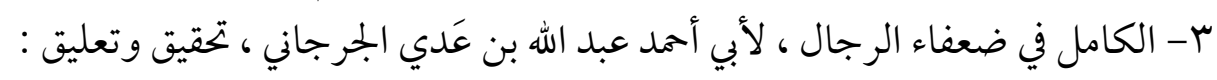

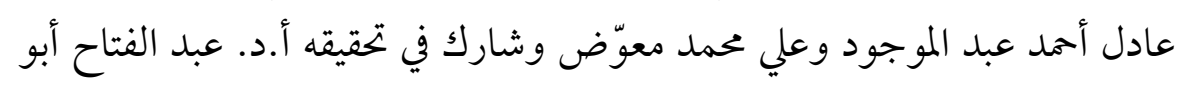

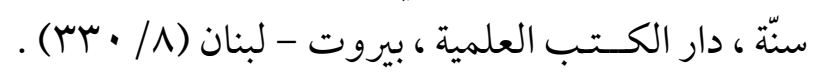

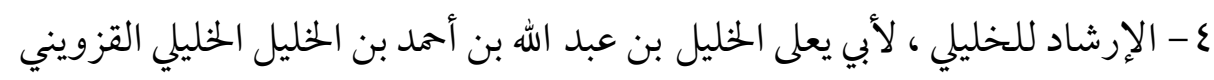

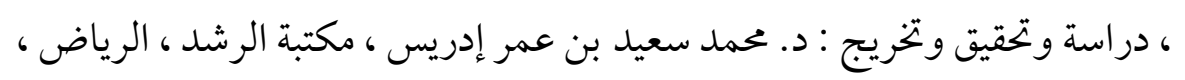

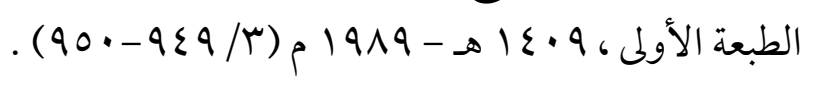




\section{المطلب الثاني : مذاهب العلماء في نبوة لقمان والراجح منها .}

$$
\text { اختلف العلم) في هذه المسألة على قولين : }
$$

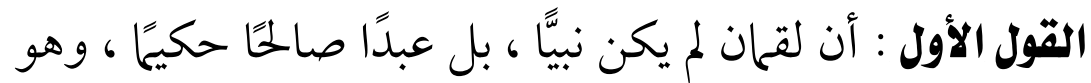

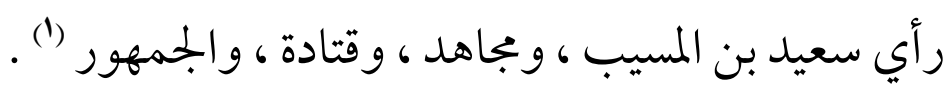

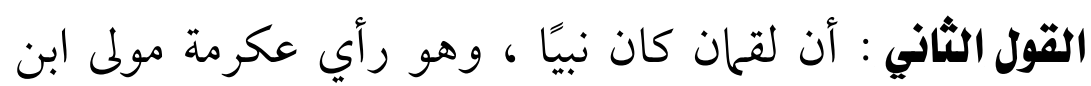

$$
\text { عباس (r) (1) }
$$

قال الثعلبي : " اتفق العلماء أنه كان حكيًًا ، ولم يكن نبيًا إلا

عكرمة فإنه يقول : إن لقمان كان نبيا ـ تفرد بهذا القول " (") .

و الراجح - والله تعالى أعلم - هو ما ذهب إليه جمهور المفسرين

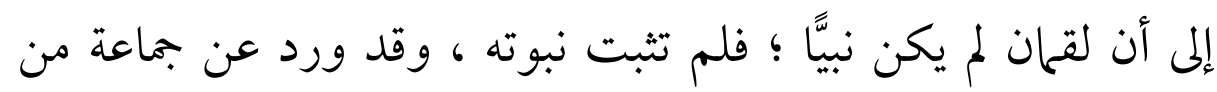

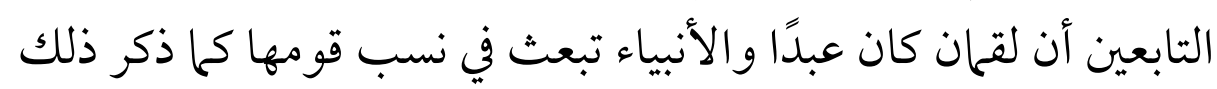

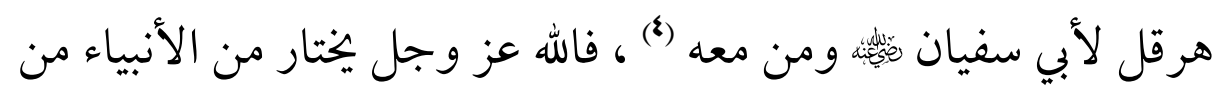

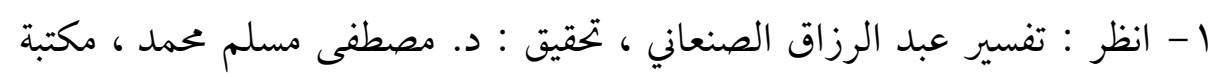

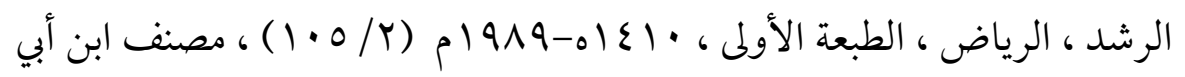

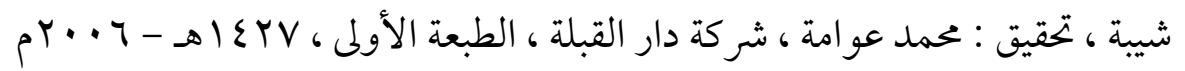

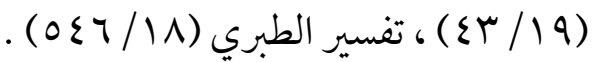

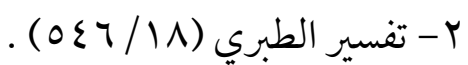

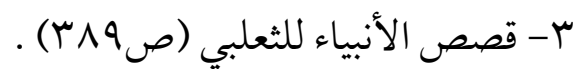

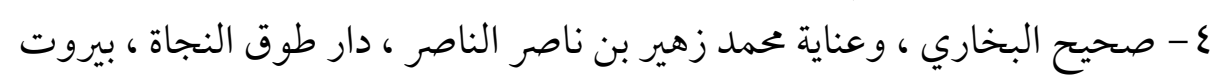

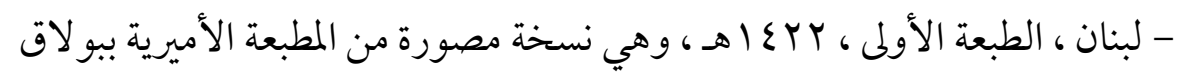

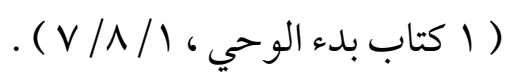


يكون شريفًا في قومه ، أما الحديث الذي ورد في نفي نبوة لقمان فهو

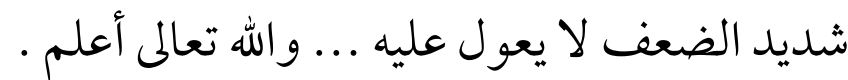

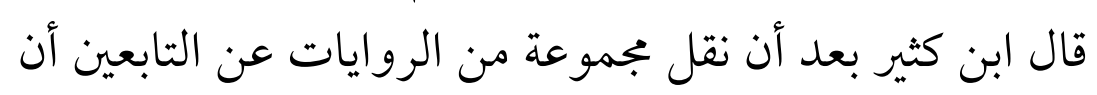

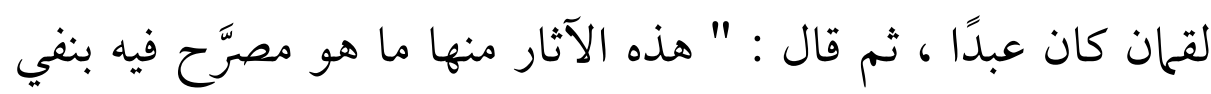

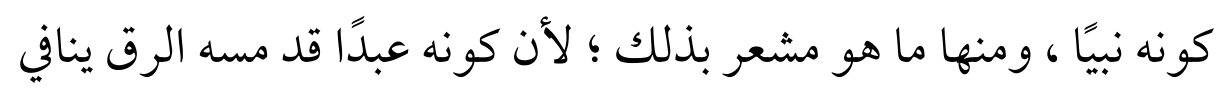

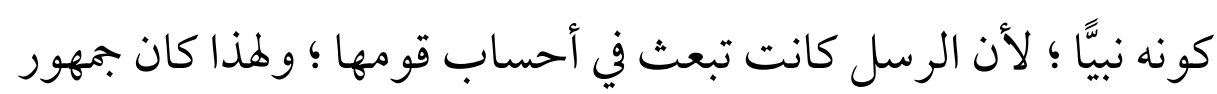

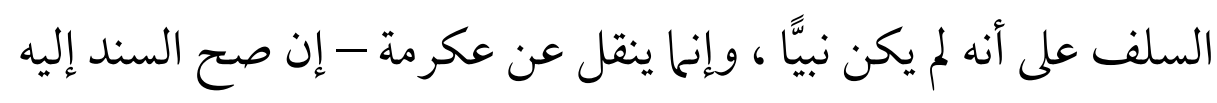

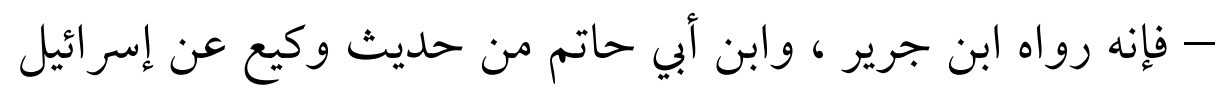

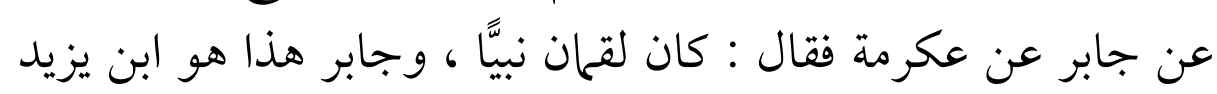

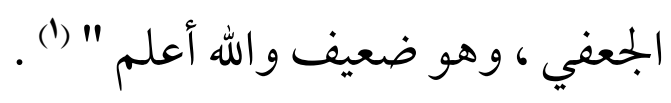

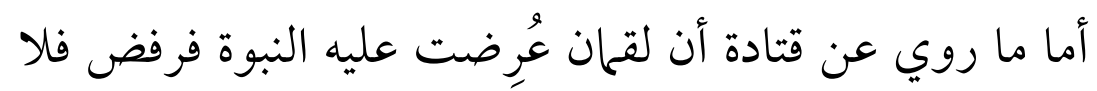

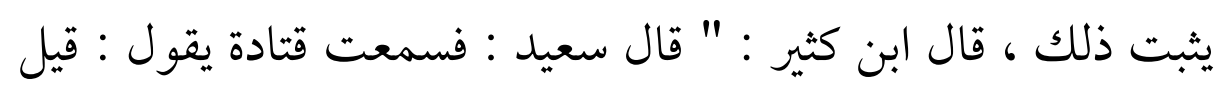

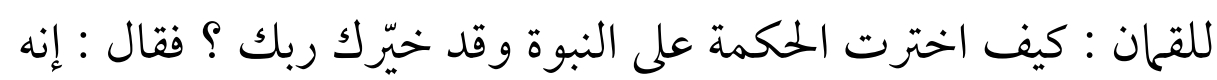

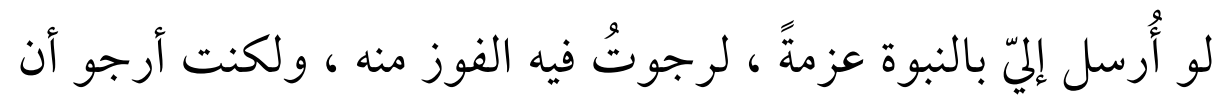

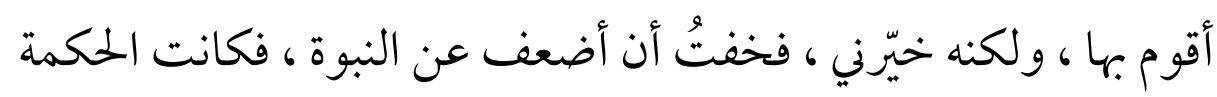

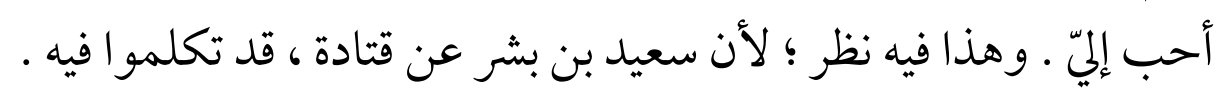

1 - تفسير ابن كثير ، لأبي الفداء إسماعيل بن عمر بن كثير القرشي الدمشقي ، تحقيق

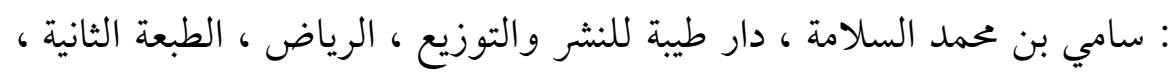

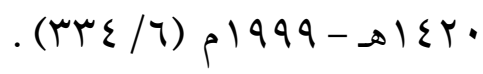


$(7 \cdot 1)$

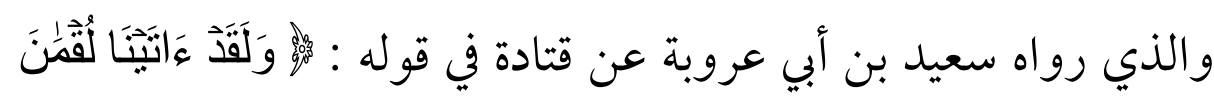

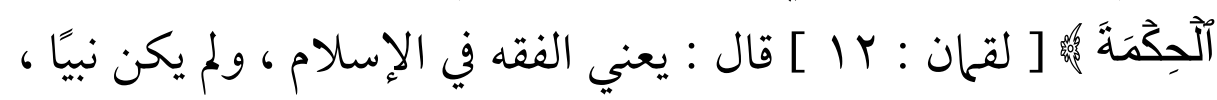

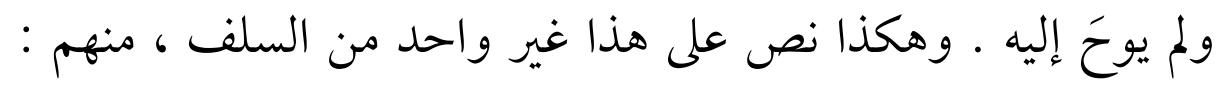

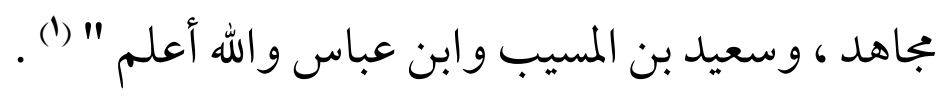

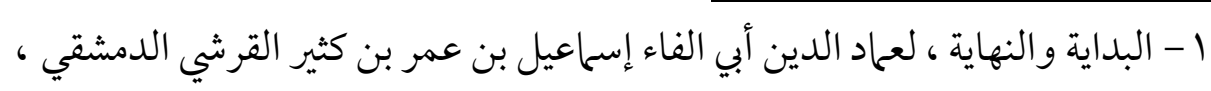

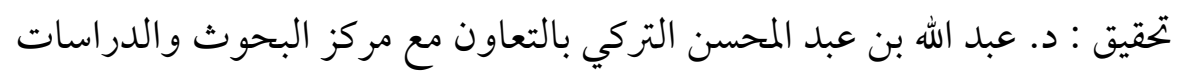

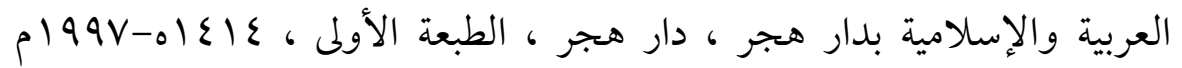




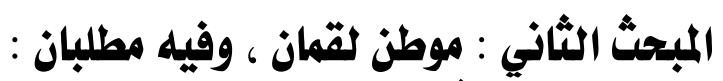

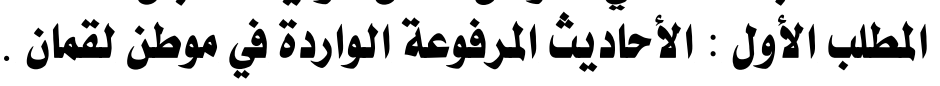

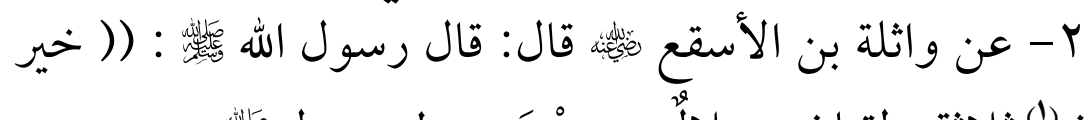

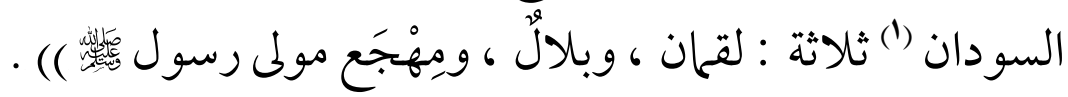

\section{: ثخريج الحديث ن}

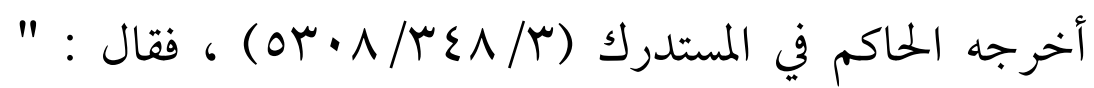

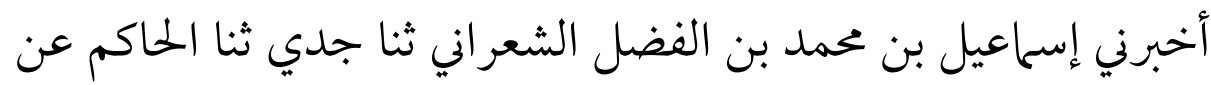

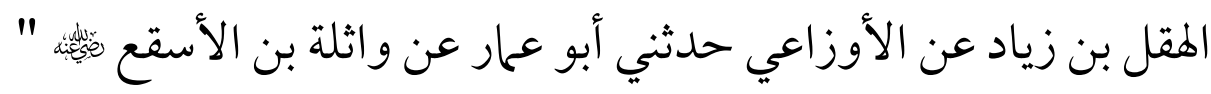

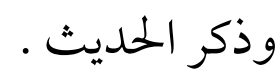

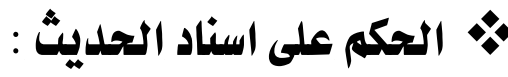

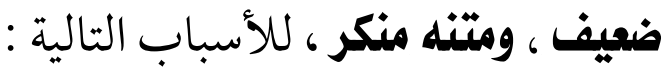

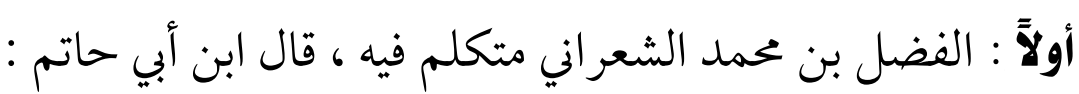

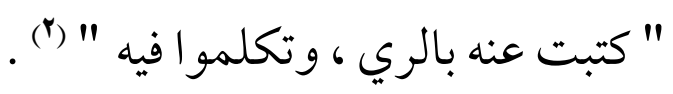

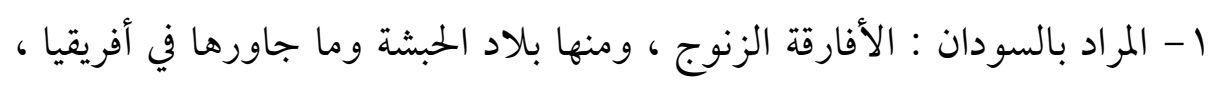

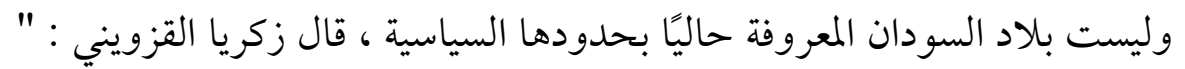

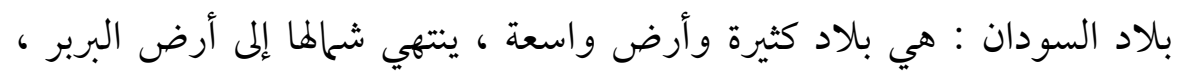

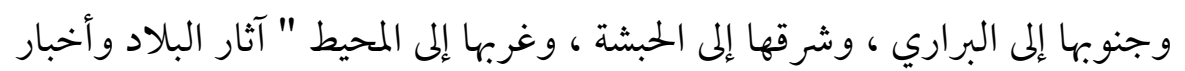

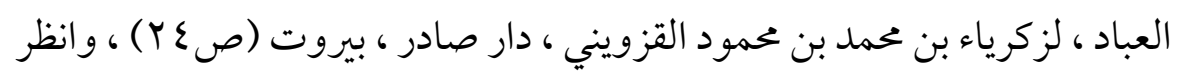

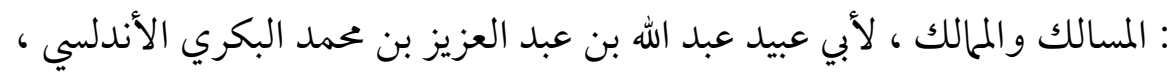

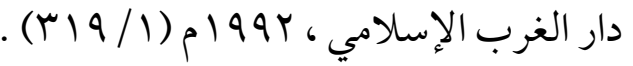

$$
\begin{aligned}
& \text { r- الجرح والتعديل (79/V) . }
\end{aligned}
$$


ثانيًا : وتكلّم أيضًا في سماع إسماعيل الشعراني من جده ، قال

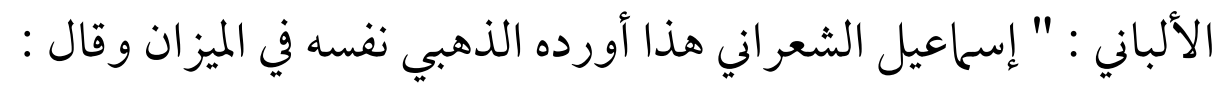

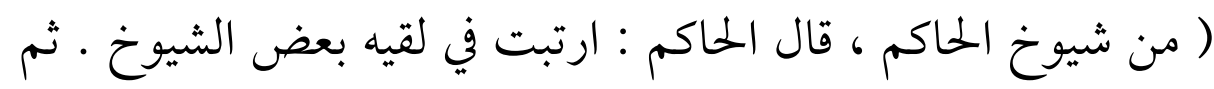

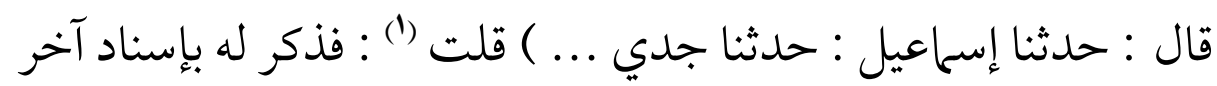

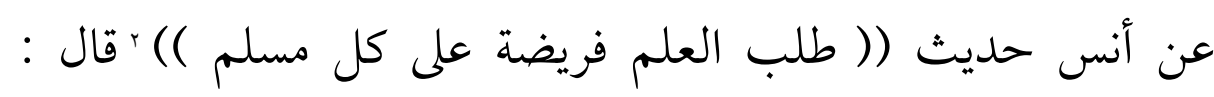

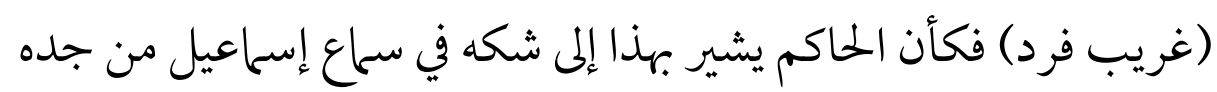

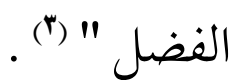

ثالثاّ : متن الحديث منكر فمهجع مولى عمر بن الخطاب وليس

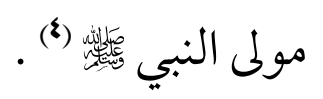
رابقًا : مهجع عربي وليس من بلاد السودان ... و الله تعالى أعلم.

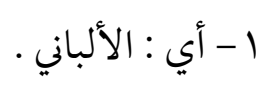

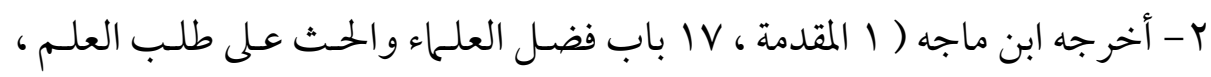

$$
\text { . ( r r } \text { ( }
$$

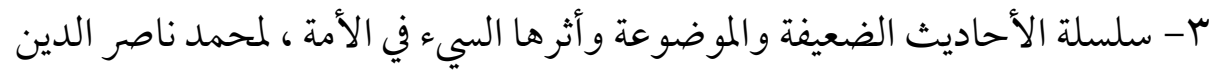

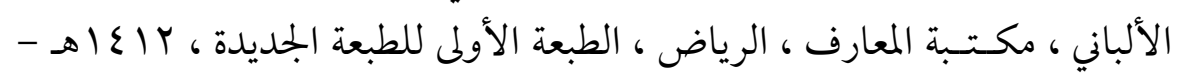

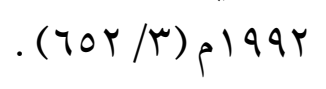

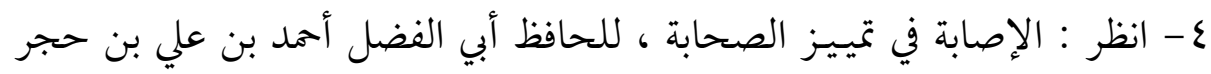

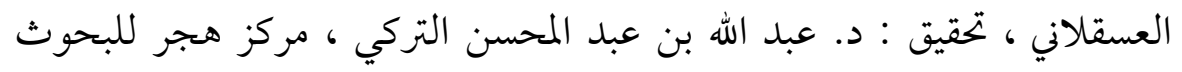

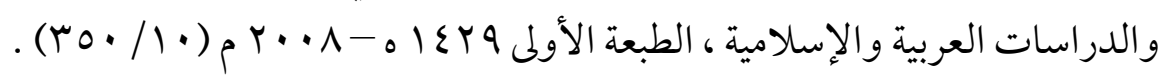


قال ابن هشام : " وِمهججَع مولى عمر بن الخطاب ، من أهل

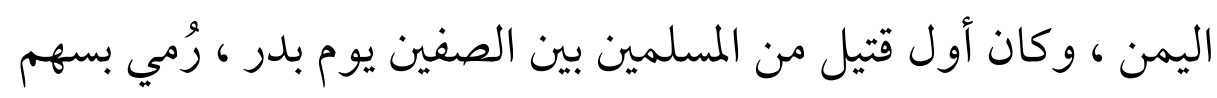

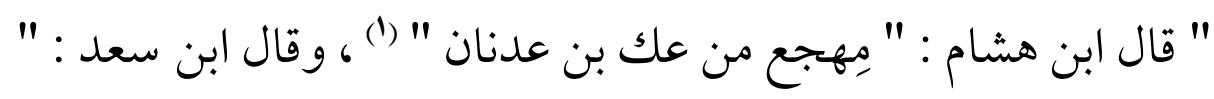

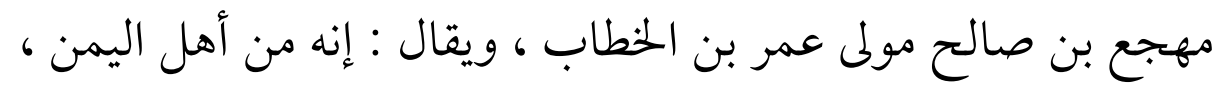

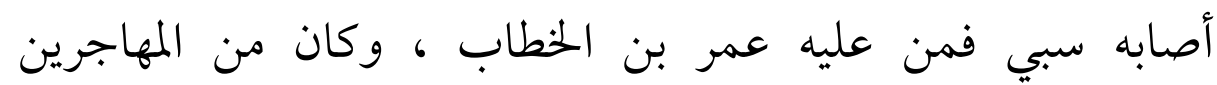

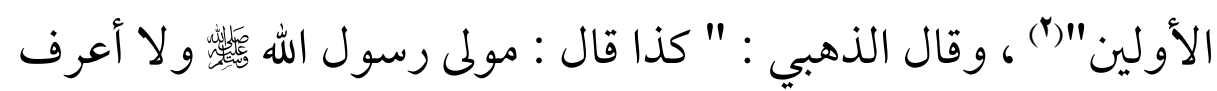

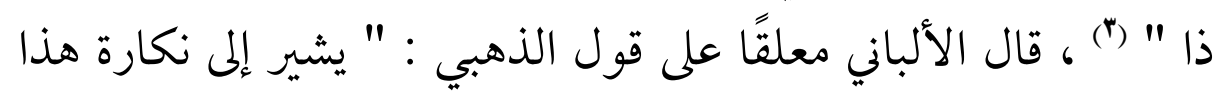

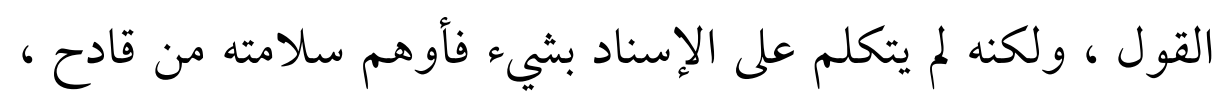

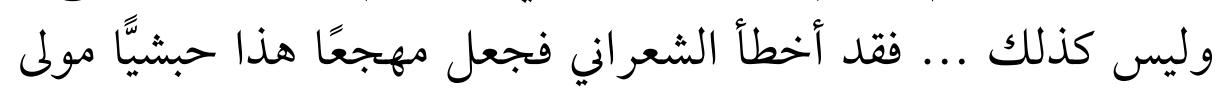

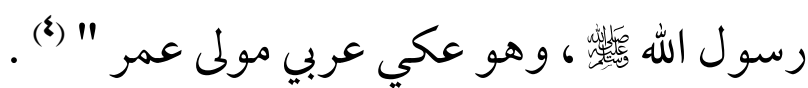

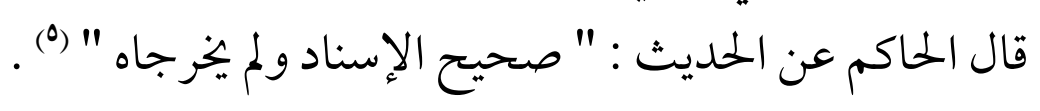
1- انظر : السيرة النبوية ، لابن هشام ، تحقيق : مصطفى السقا وإبراهيم الأبياري

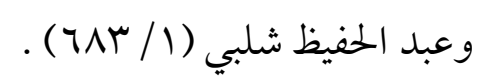

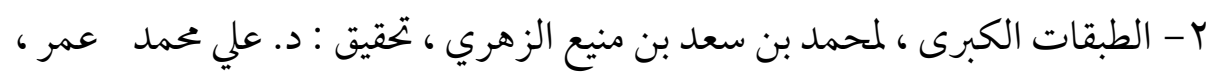

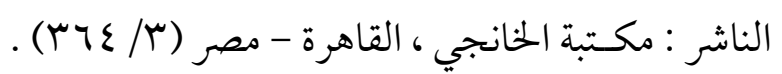

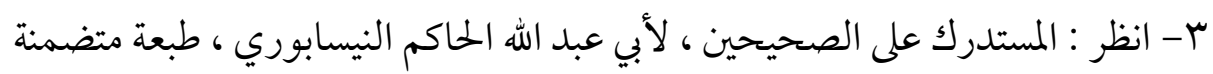

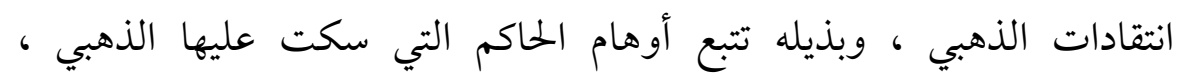

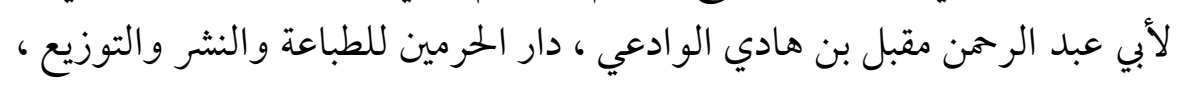

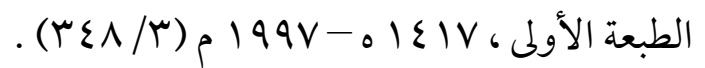

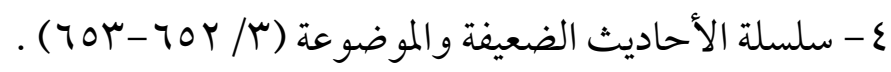

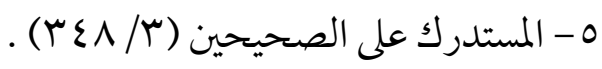




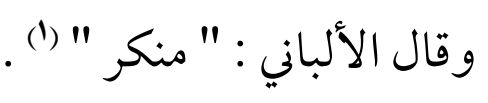

بَ- عن ابن عباس قال : قال رسول الله

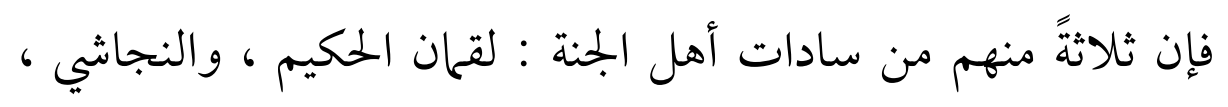

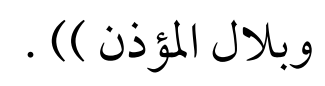

\section{خ : تخريج الحديث :}

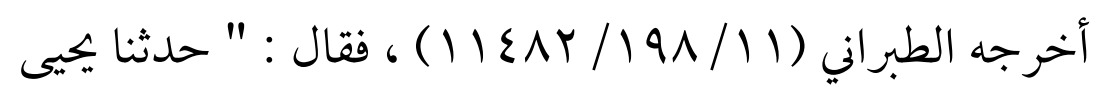

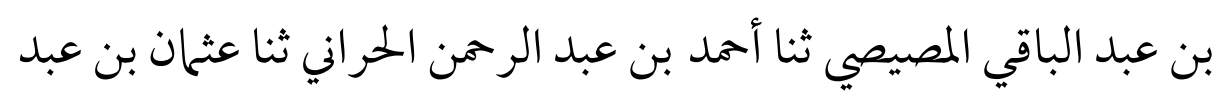

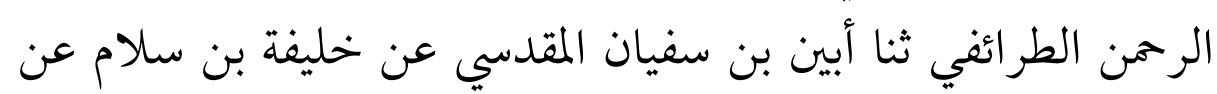

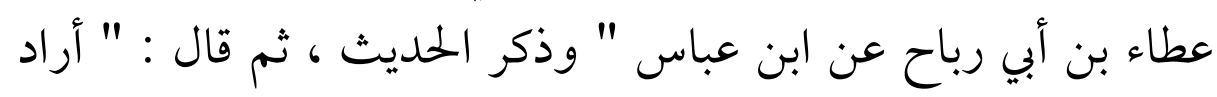

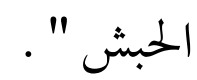

وأخر جه من طريقه ابن عساكر في تاريخ دمشق ( • / / T ع ) به.

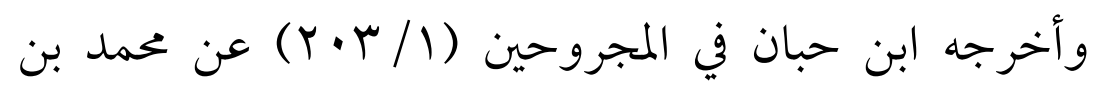

كلاهما : ( يحيى بن عبد الباقي ، ومحمد بن المسيب ) عن أحمد بن

$$
\text { المسيب به . }
$$

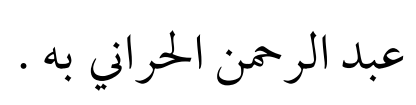

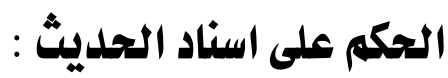

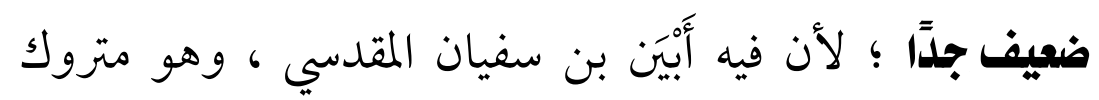

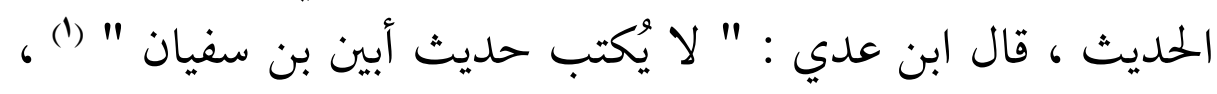

$$
\text { 1- سلسلة الأحاديث الضعيفة والموضوعة (r/ } 1 \text { (70) . }
$$




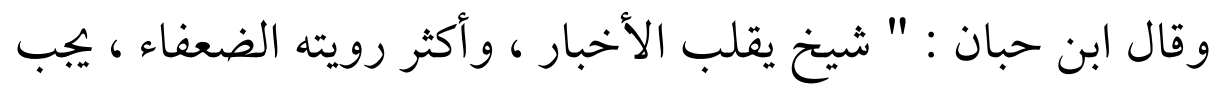

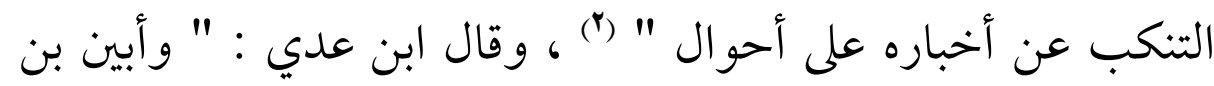

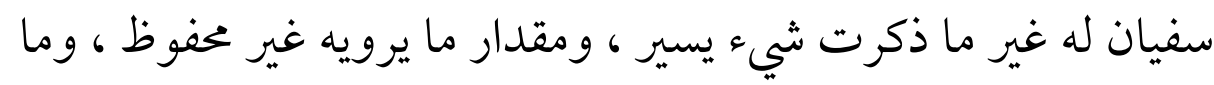

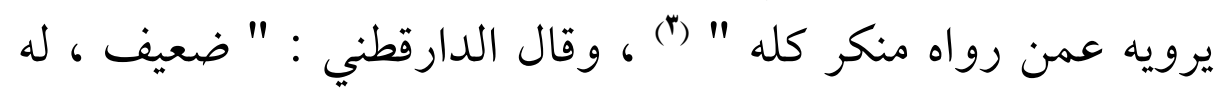

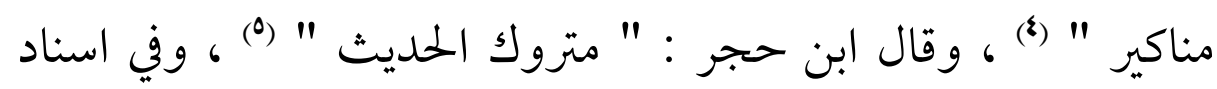

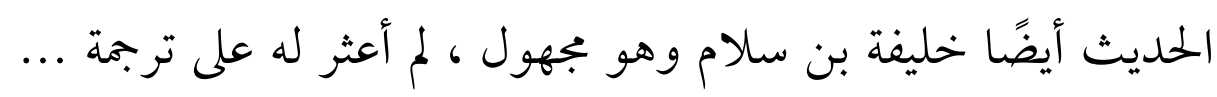
والله تعالى أعلم . آلحان. قال ابن حبان : " هذا متن باطل لا أصل له " (7) .

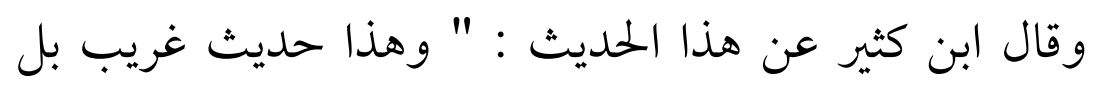
منكر ") "(v) وقال الألباني : " ضعيف جدًا " (A) . .

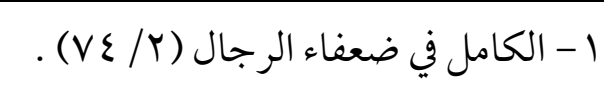

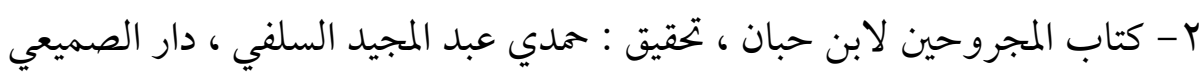

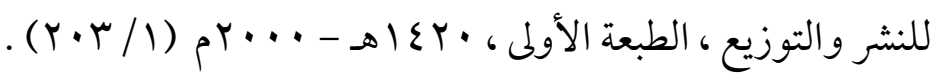

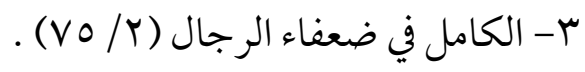

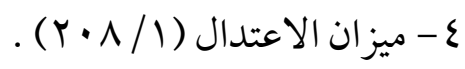

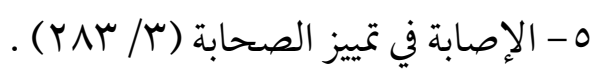

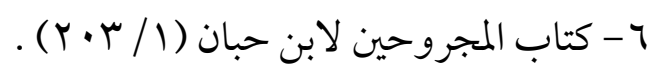

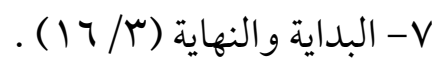

$$
\begin{aligned}
& \text { 1- سلسلة الأحاديث الضعيفة والموضوعة (T/ / آIا ) . }
\end{aligned}
$$


$(7 \cdot V)$

المطلب الثاني : مذاهب العلماء في موطن لقمان .

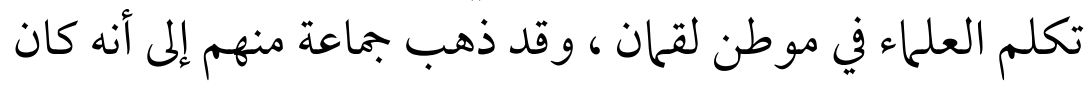

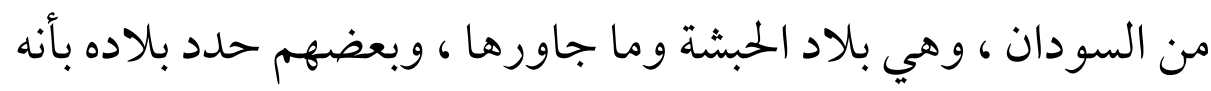

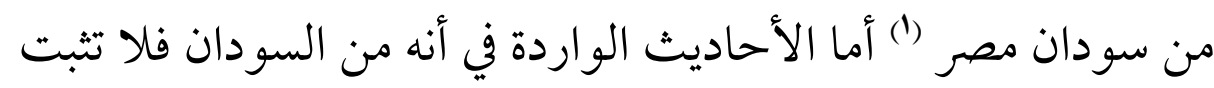

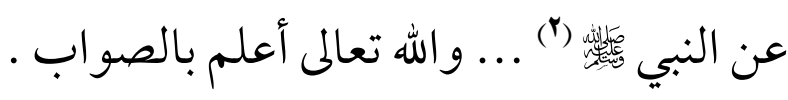

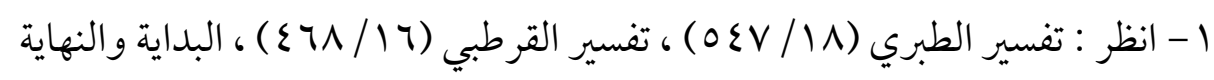

. ( $7 / r)$

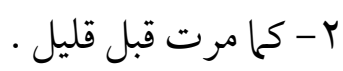




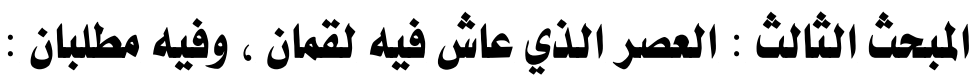

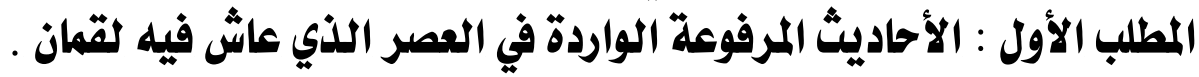

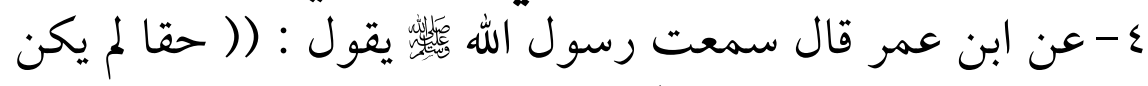

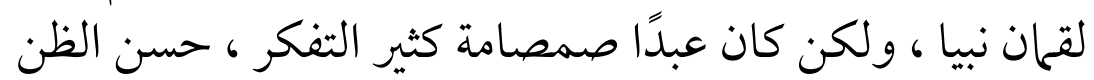

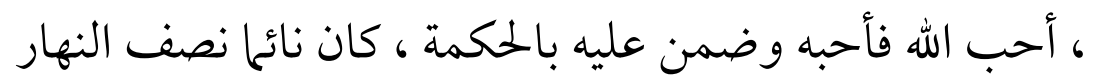

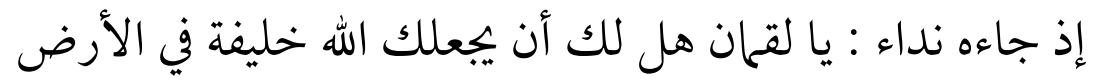

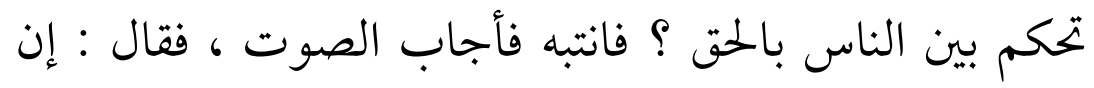

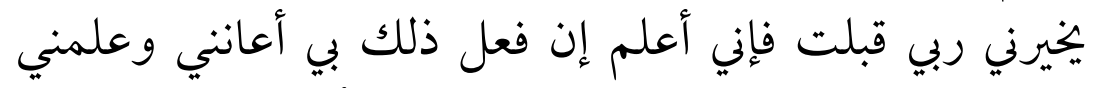

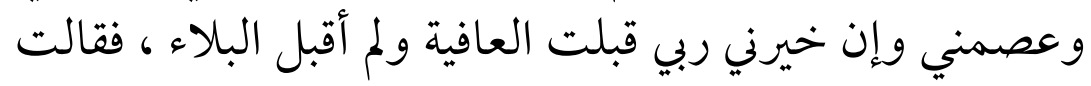

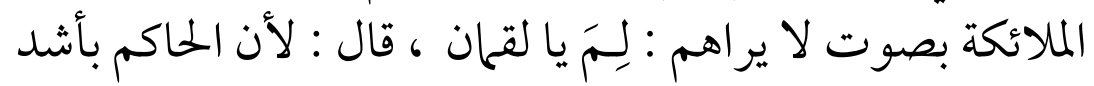

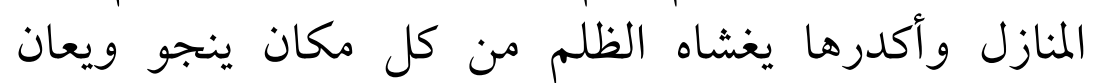

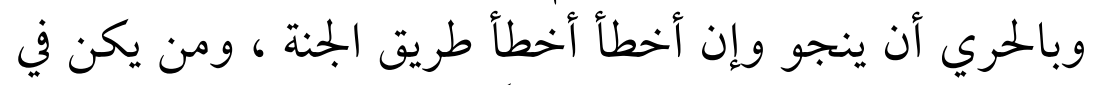

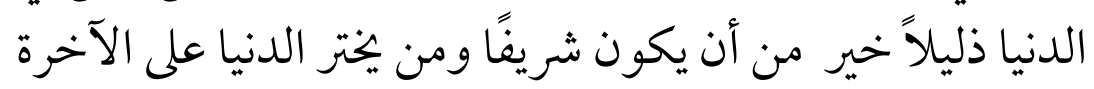

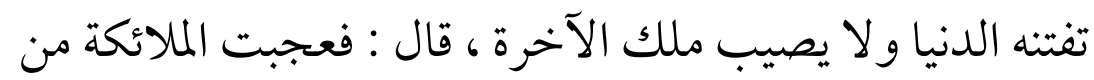

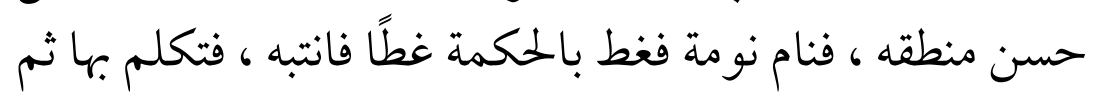

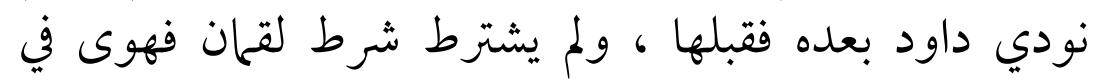

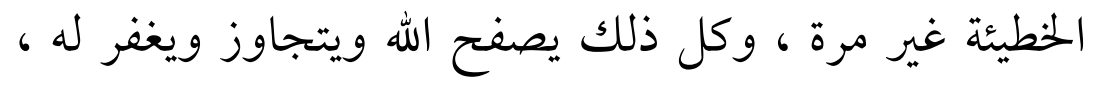

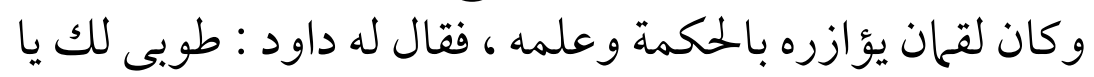

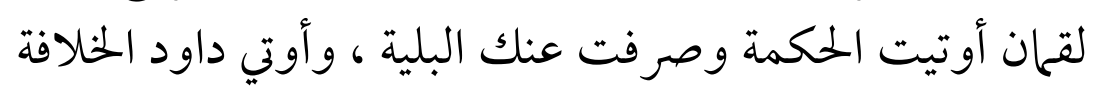
وابتلي بالرزية أو الفتنة ) ).

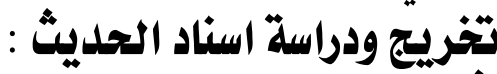

شديل الضعيف،سبق تخريجه ودر اسة اسناده في حديث رقم: (1) : 
$(7 \cdot 9)$

\section{المطلب الثاني : تحديد العصر الذي عاش فيه لقمان .}

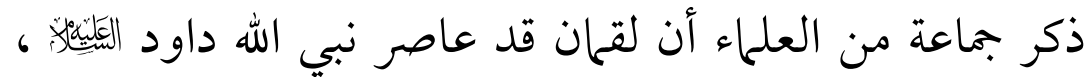

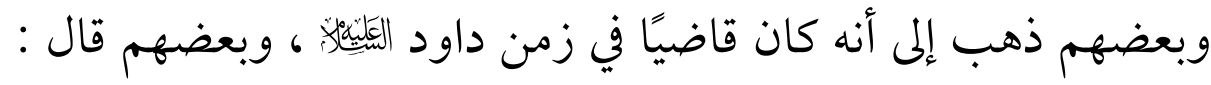

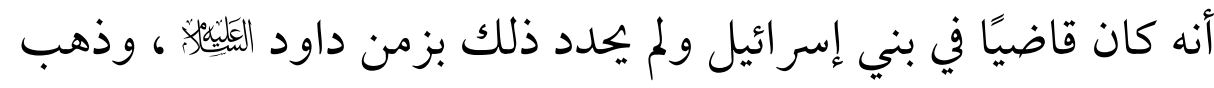

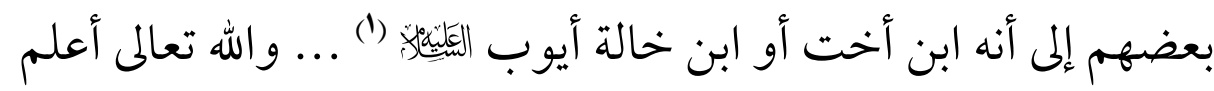

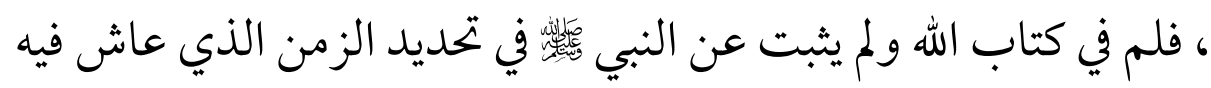

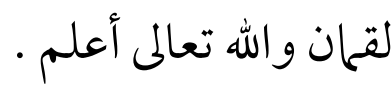

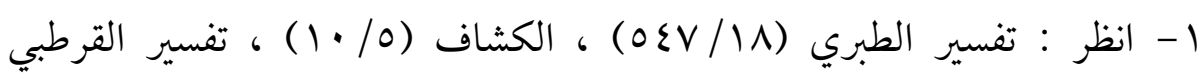

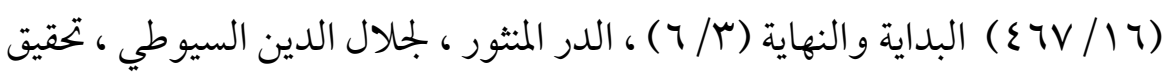

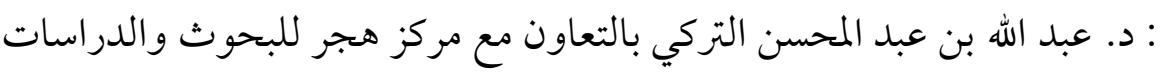

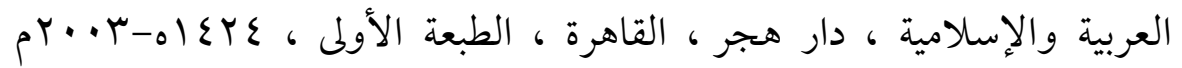


(7)

\section{المبحث الرابع : شفاعته يوم الثيامة للمسلمين .}

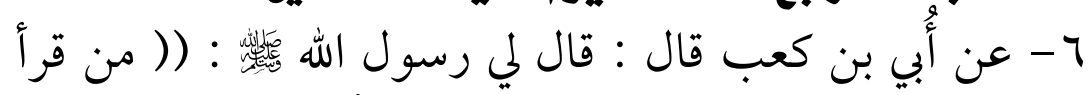

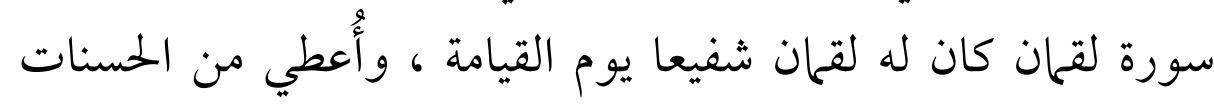
عشرًا ، بعدد من عمل بالمعروف وعمل بالمنكر ) ) .

: تخريج الحديث :

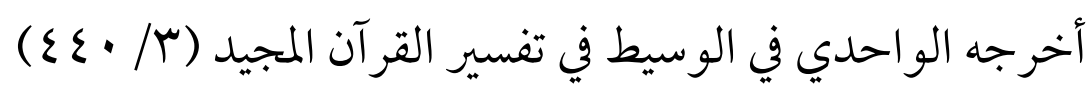

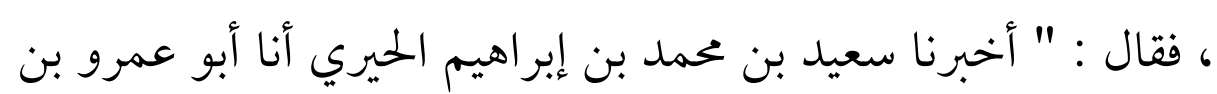

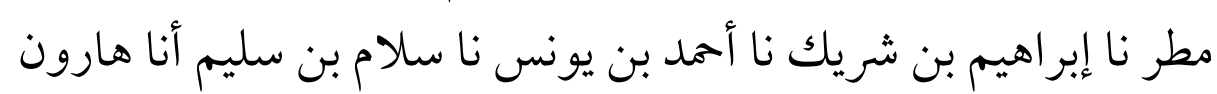

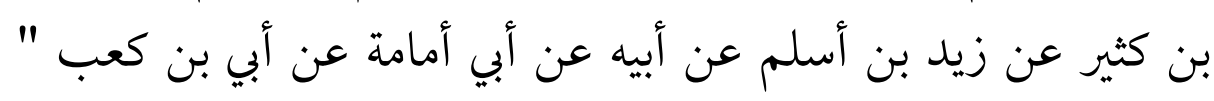
وذكر الحديث . منير

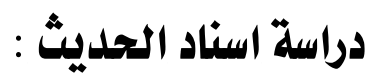

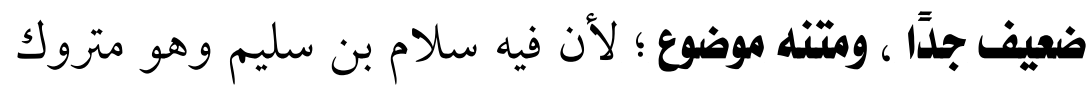

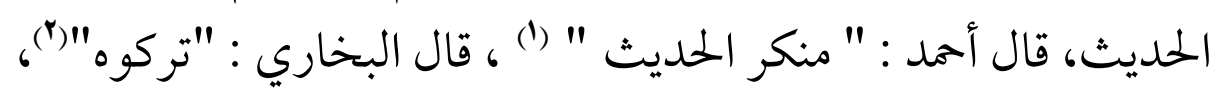

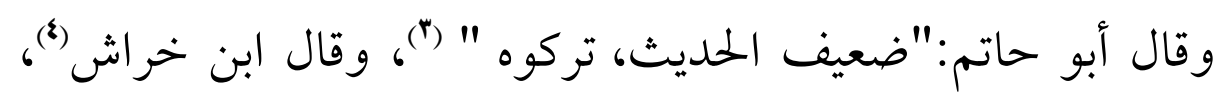

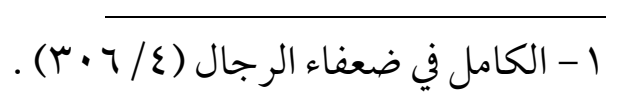

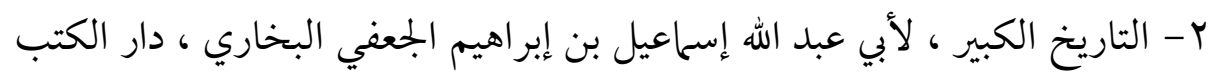

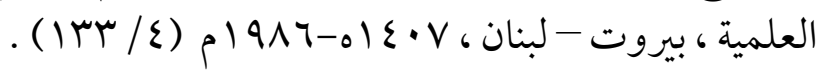

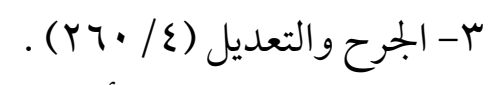

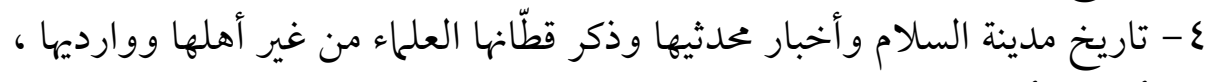

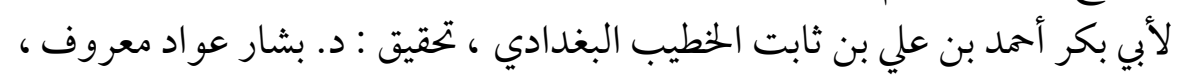

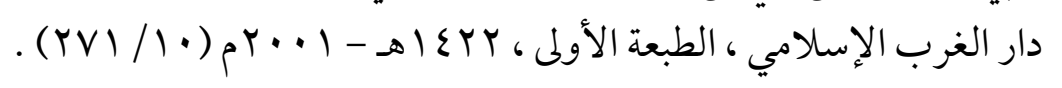


(7II)

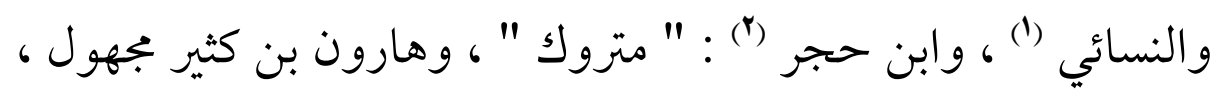

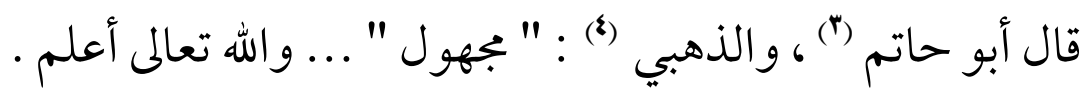
قال ابن عدي : " هارون بن كثير شيخ ليس بمعروف روى عن عن وعن

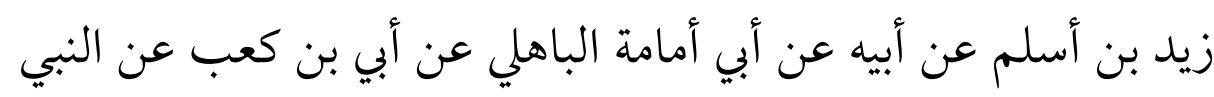

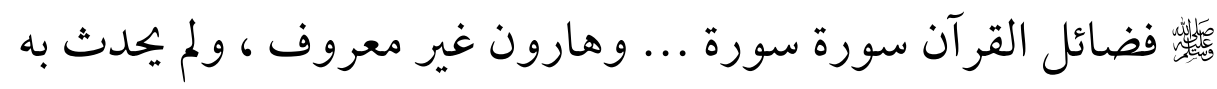

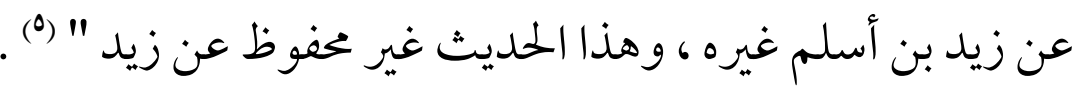

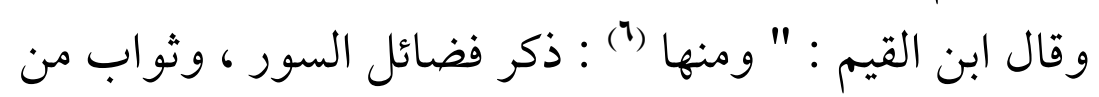
قرأ سورة كذا فله كذا ، من أول القرآن إلى آخره ـ كما يذكر ذلك الثعلبي

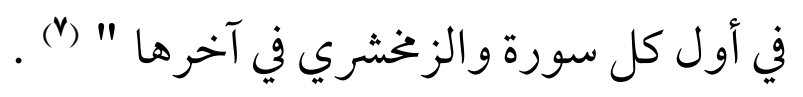

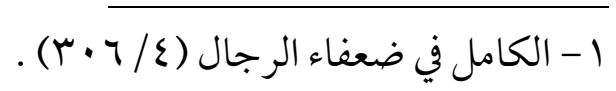

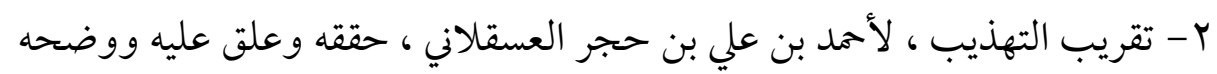

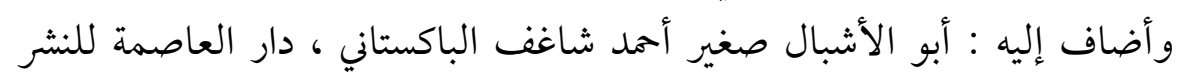

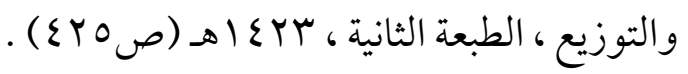

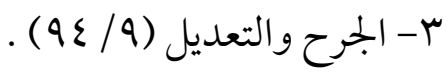

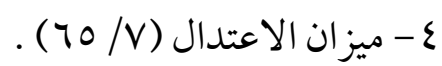

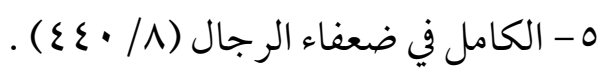

$$
\begin{aligned}
& \text { 7- أي الأحاديث التي لم تثبت . }
\end{aligned}
$$

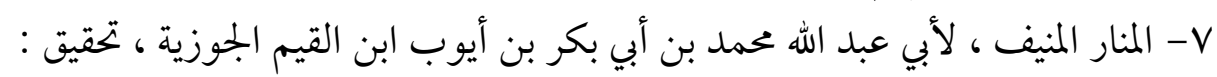

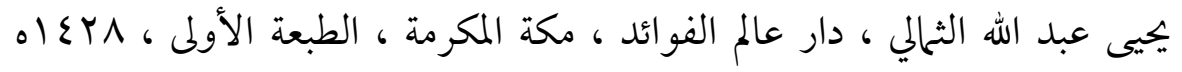


وذكر السيوطي بجموعة من الطرق الباطلة عن أبي بن كعب في

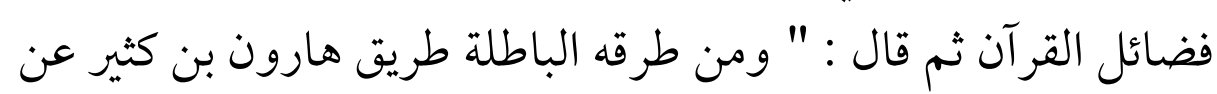

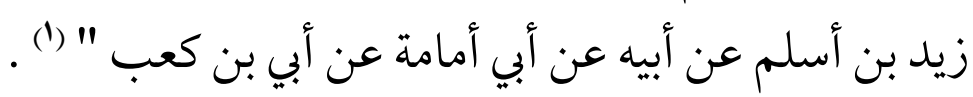

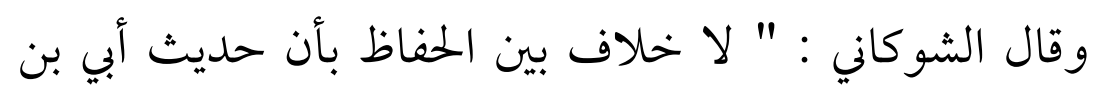
كعب هذا موضوع · وقد اغتر به جماعة من المفسرين فذكروه في تفاسيرهم : كالثعلبي والواحدي والزخشري ، ولاع ولا جرم فليسوا من

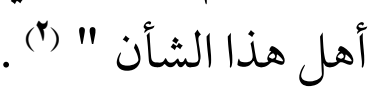

1 - اللالكئ المصنوعة في الأحاديث الموضوعة ، لجلال الدين السيوطي ، دار المعرفة ،

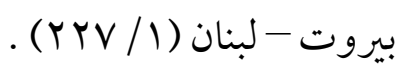

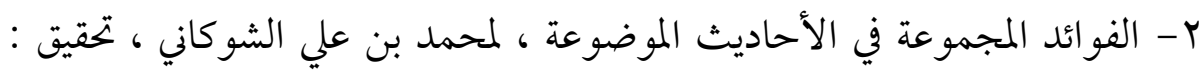

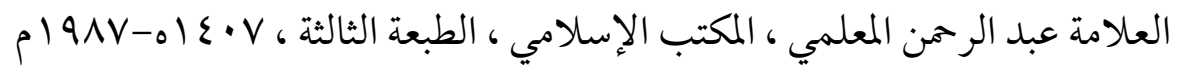

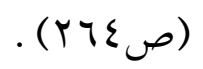


(7/r)

\section{المبحث الخامس : الحديث المرفوع الوارد في حكمة وأقوال لقمان}

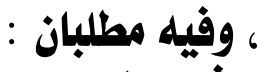

المطلب الأول : الحديث المرفوع الوارد في حكمة لقمان .

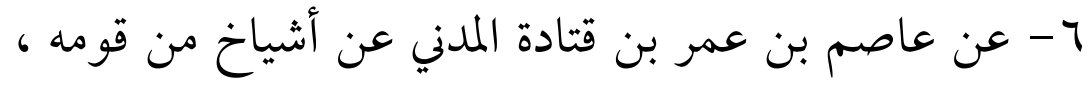

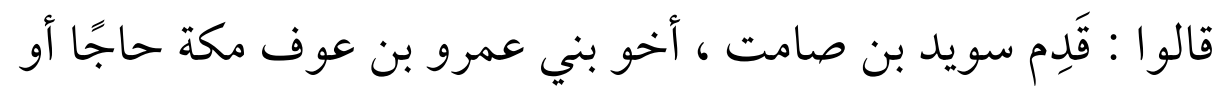

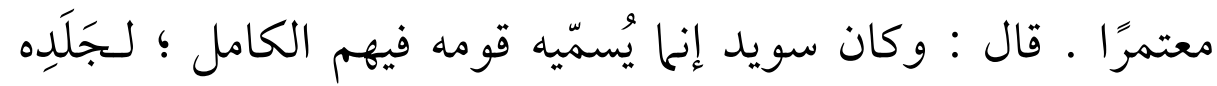

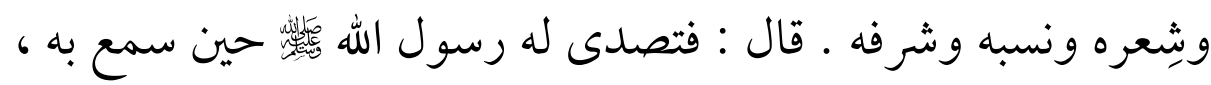

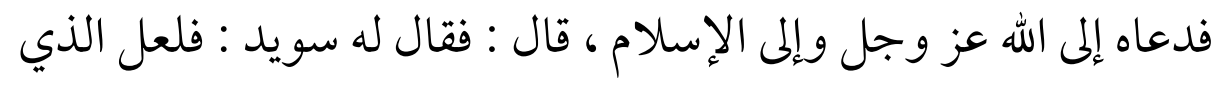

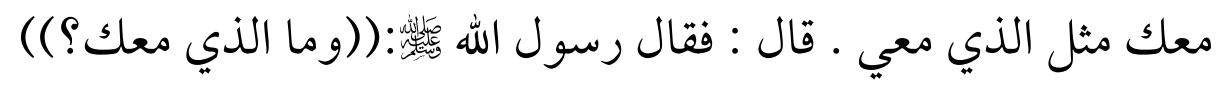
قال : مجلة لقمان - يعني حكمة لقمان - فقال له رسول الله فئل

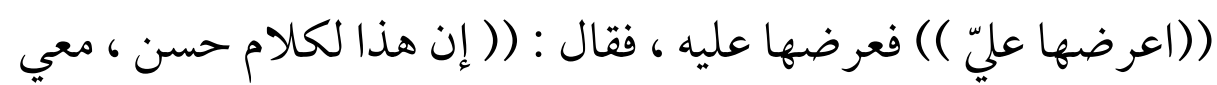

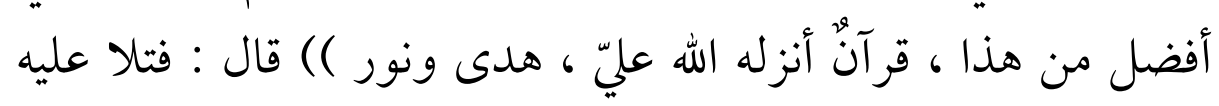

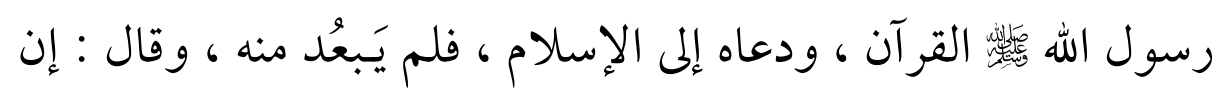

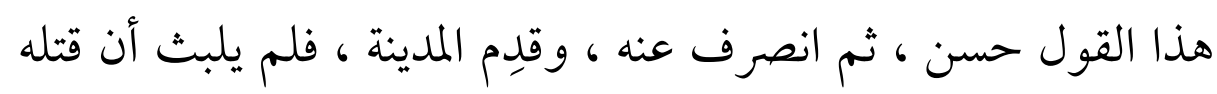

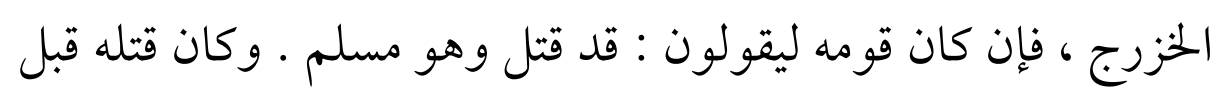

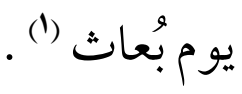

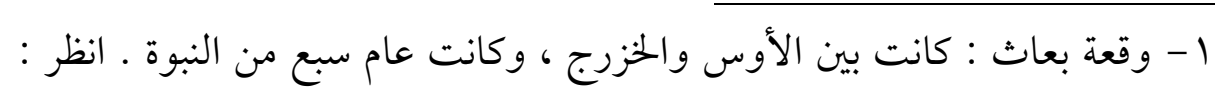

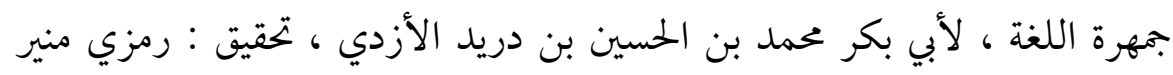

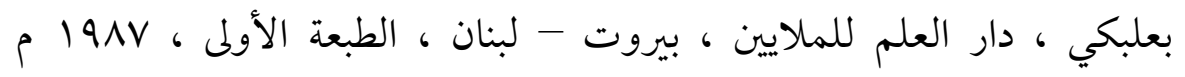

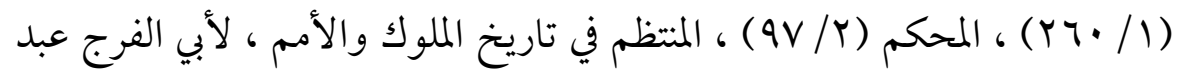

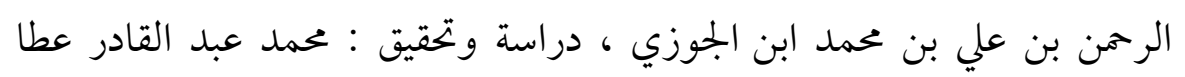




\section{تخريج الحديث : تخرئ}

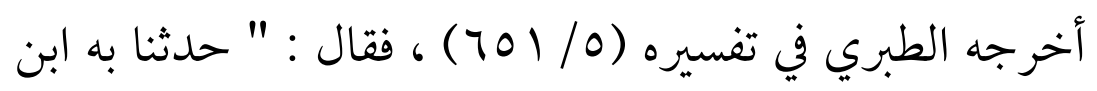

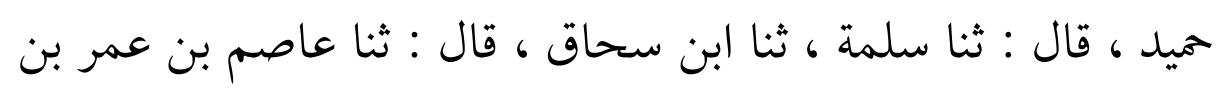
قتادة المدني عن أشياخ من قومه " وذكر الحديث .

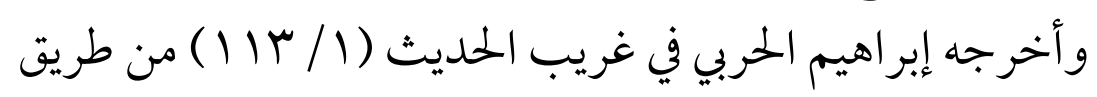

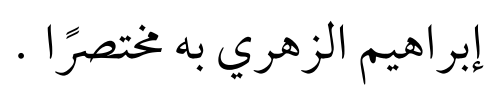

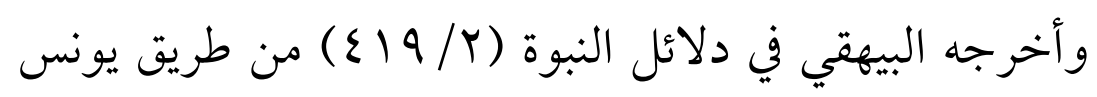

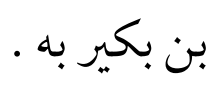
ثلاثتهم : ( سلمة ، وإبراهيم الزهري ، ويونس بن بكير ) عن

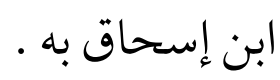

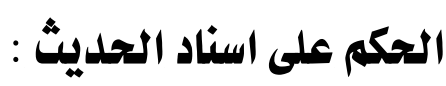

ضعيف ؛ لأن جميع طرقه مبناها على بجاهيل .... والله تعالى أعلم .

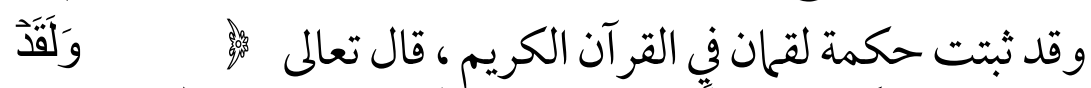

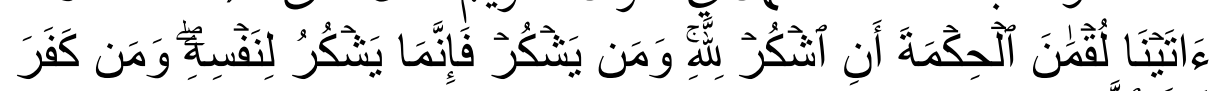

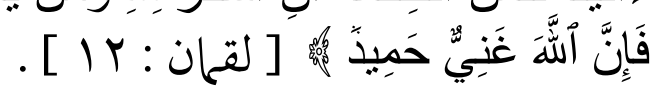

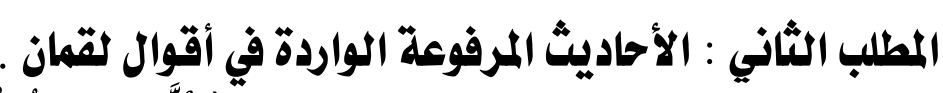

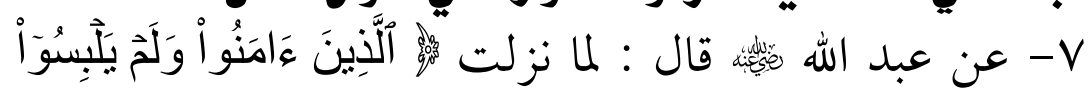

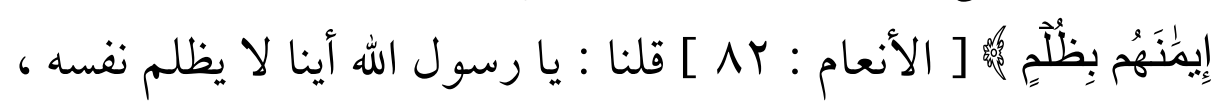

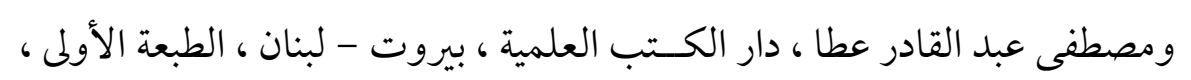

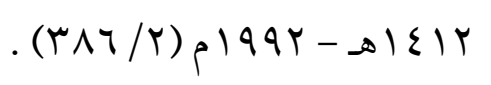


(710)

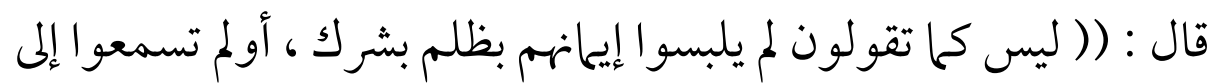

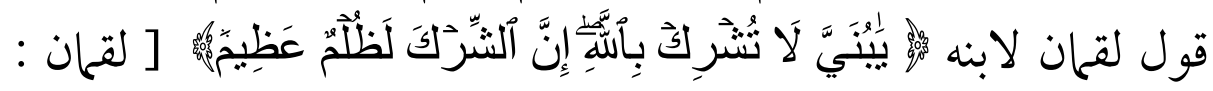
. ( [ [

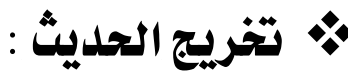

أخرجه البخاري ( •ج كتاب أحاديث الأنبياء ، باب قول الهُ

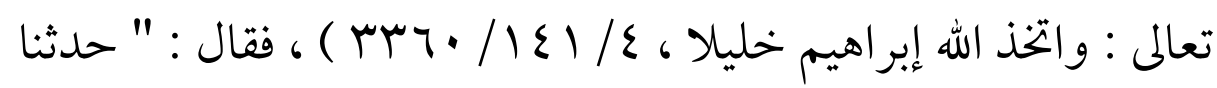

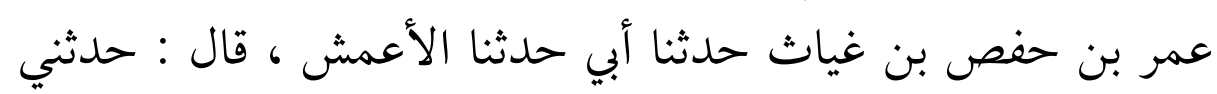

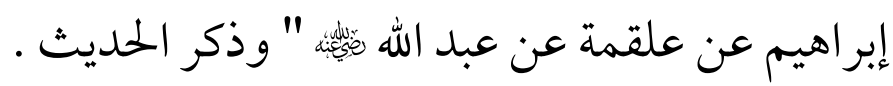

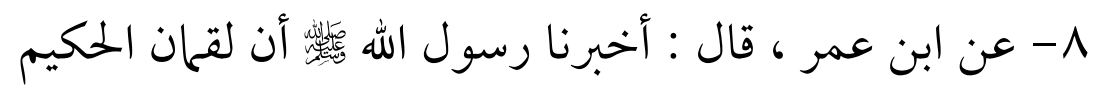

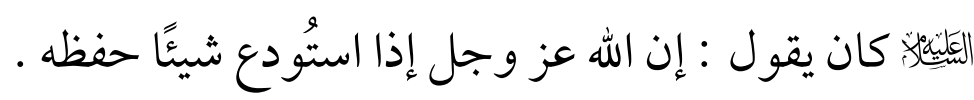

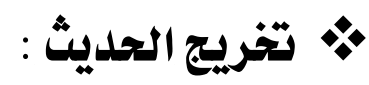

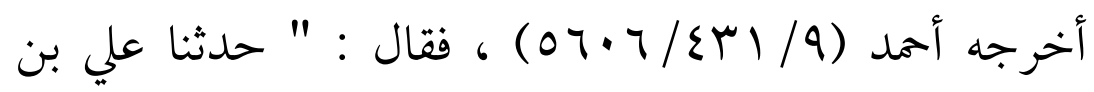

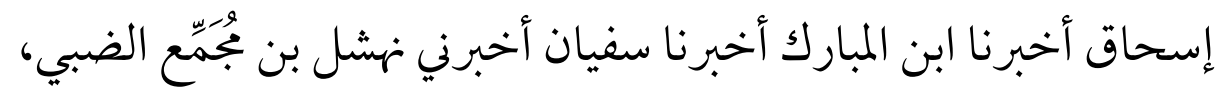

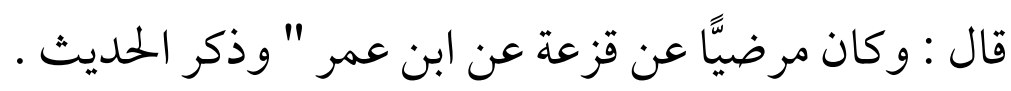

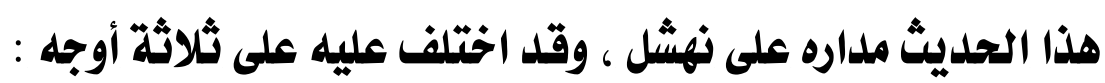

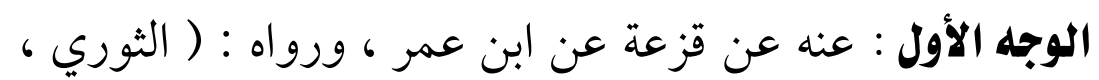

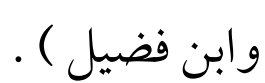

الوجه الثاني : عنه عن أبي غالب عن ابن عمر ، ورواه : 
الوجه الثالث : عنه عن قزعة أو أبي غالب عن ابن عمر ، ورواه :

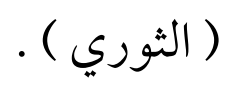

رواه الثوري وقد اختلف عليه على وجهين ، واختلف عليه على

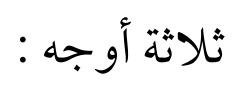

الوجه الأول : عنه عن نهشل عن قزعة عن ابن عمر ، ورواه :

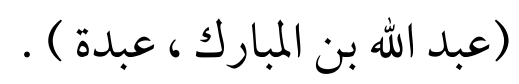

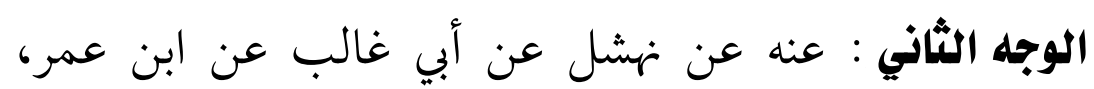

$$
\text { ورواه: (إسحاق بن الأزرق ، وقبيصة ، وأبو داود الحفري). }
$$

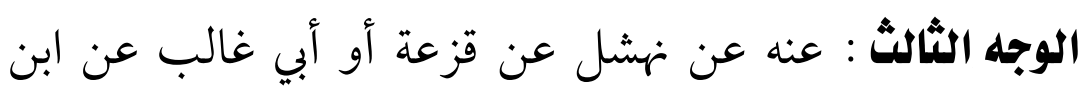

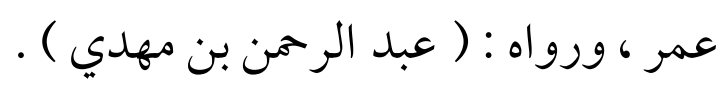

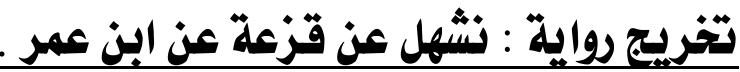

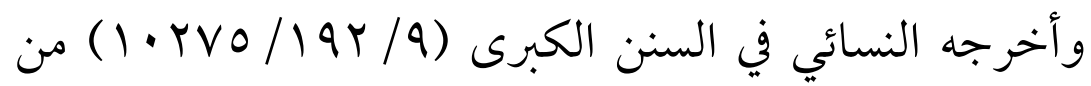

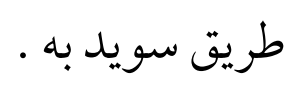

كلاهما : ( علي بن إسحاق ، وسويد ) عن عبد الله بن المبارك .

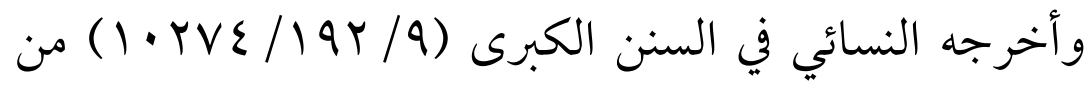

طريق عبدة نحوه.

$$
\text { كلاهما : ( عبد الله بن المبارك ، وعبدة ) عن الثوري . }
$$

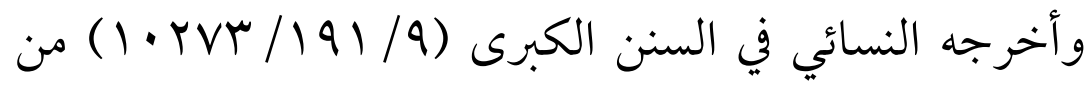

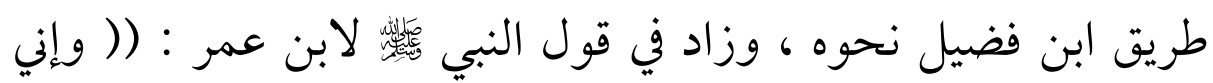
أستودع الله دينك ، وأمانتك ، وخو اتم عملك ، وأقر أ عليك السلام) ). 
كلاهما : ( الثوري ، وابن فضيل ) عن نهشل بن بُجمِّع به .

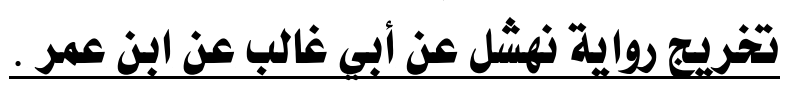

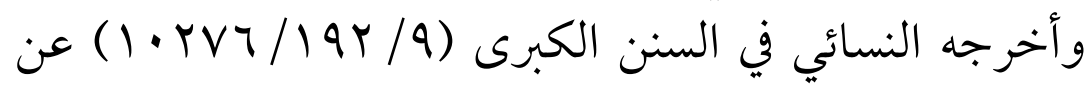

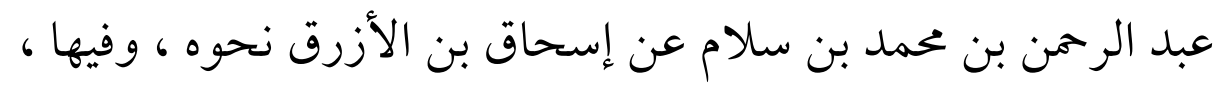

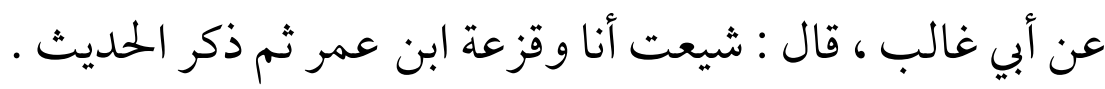

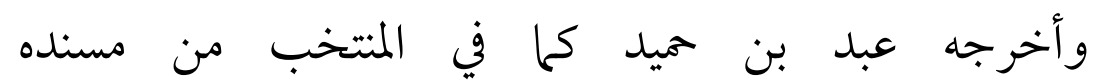

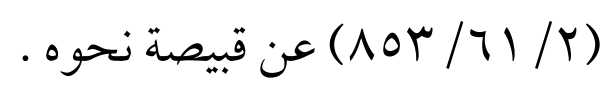

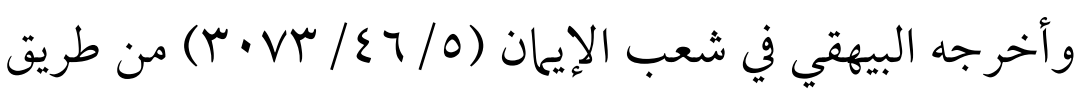

$$
\text { أبو داود الحفري نحوه . }
$$

ثلاثتهم : ( إسحاق بن الأزرق ، وقبيصة ، وأبو داود الحفري )

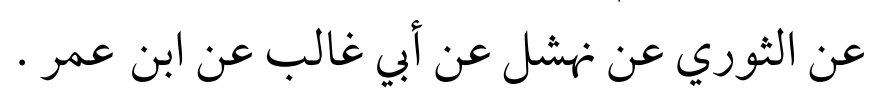

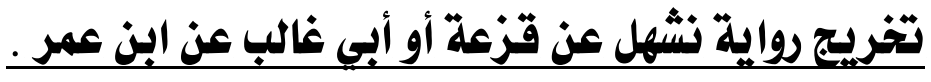

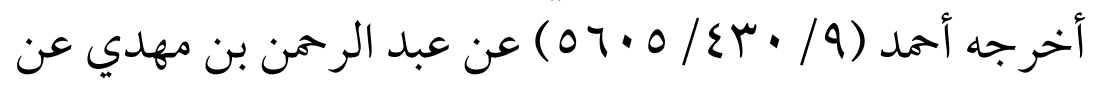

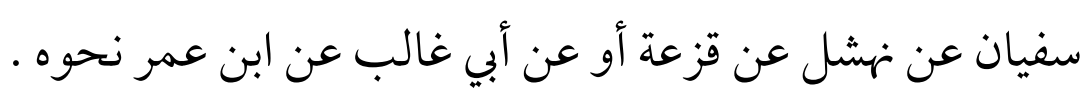

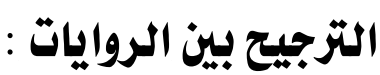

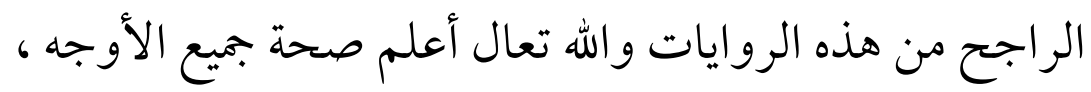

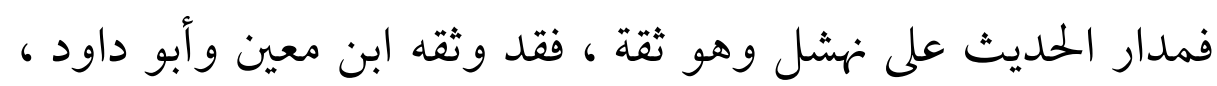

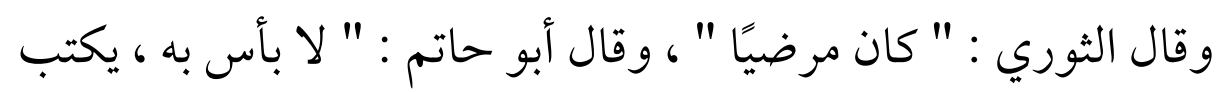


حديثه " (1) ، والرواة عنه ثقات ، فلا يمنع من أن نهشل قد سمع

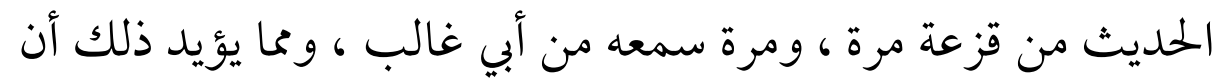

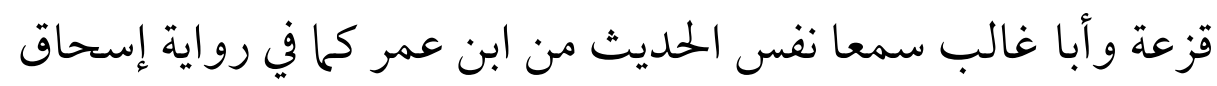

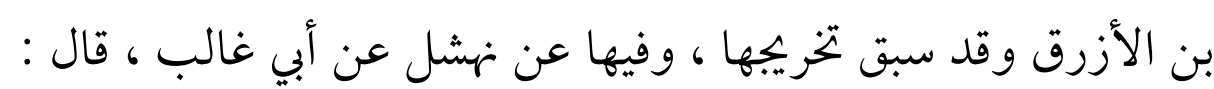

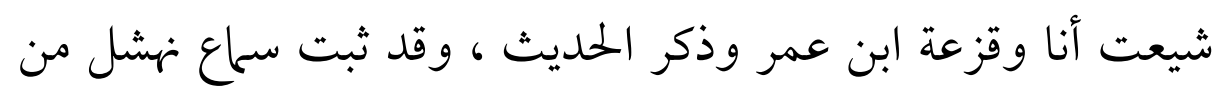

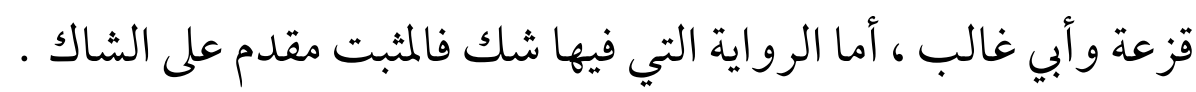

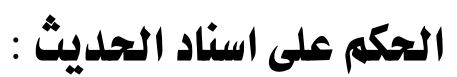

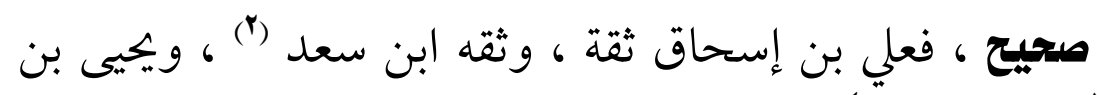

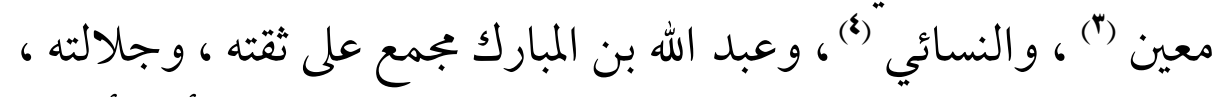

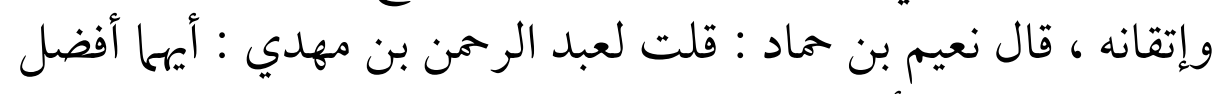

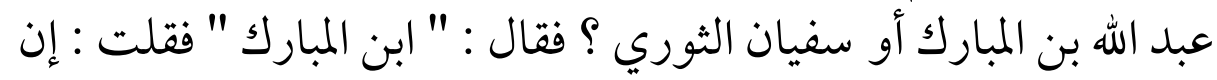

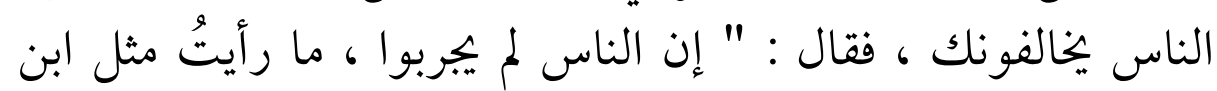

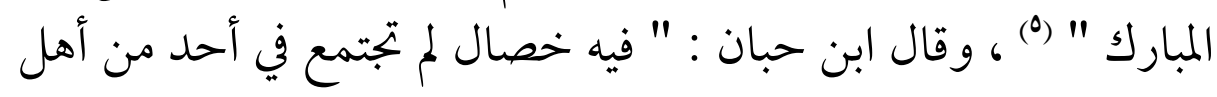

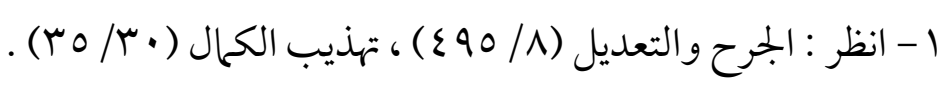

$$
\begin{aligned}
& \text { r - الطبقات الكبرى (rVT/V) . }
\end{aligned}
$$

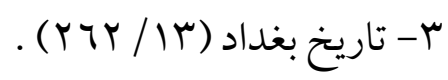

$$
\begin{aligned}
& \text { ع - تهذيب الكمال (• ( } 19 / \text { (r) . } \\
& \text { - الجرح والتعديل (IV9/0) . }
\end{aligned}
$$


(7/9)

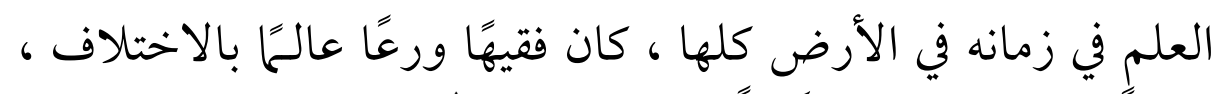

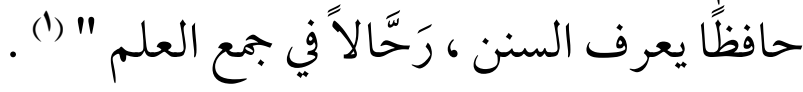

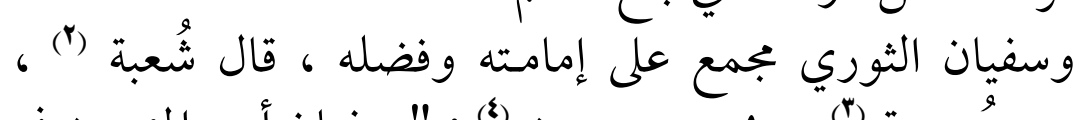

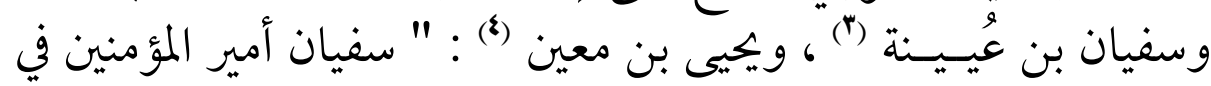

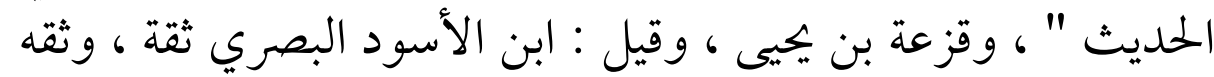

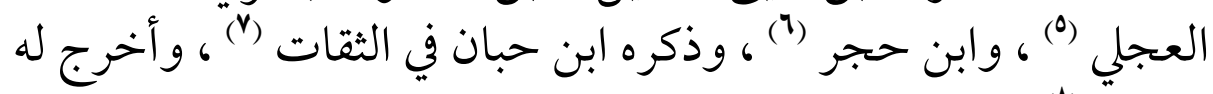
الجماعة الجيلي قال العراقي عن هذا الحديث : " إسناده جيد " (9) ، وحسّن

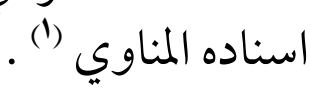

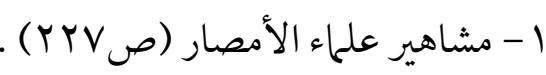

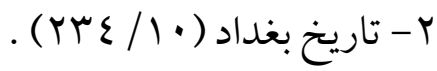

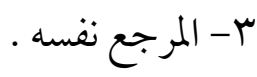

$$
\begin{aligned}
& \text { ع - المرجع نفسه . المرجع نفه ه }
\end{aligned}
$$

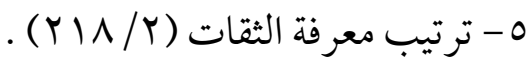$$
\text { 1 - تقريب التهذيب (صن ع ع ) . }
$$

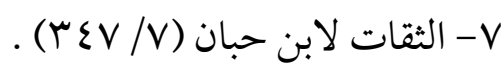

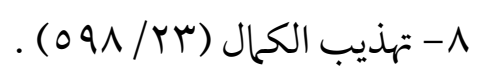

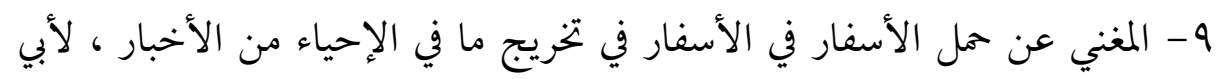

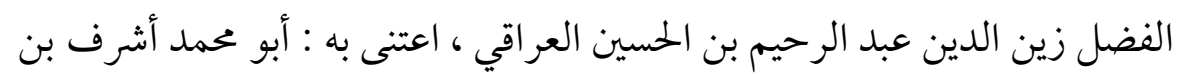

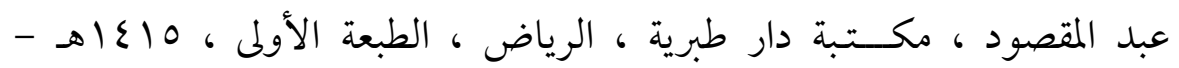
. (oor/1) p 1990 
$(T r \cdot)$

الأحاديث المرفوعة الواردة في لقمان

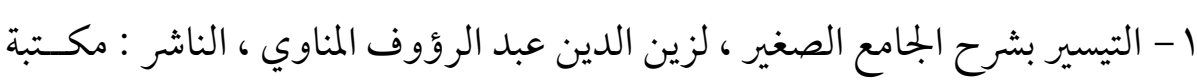

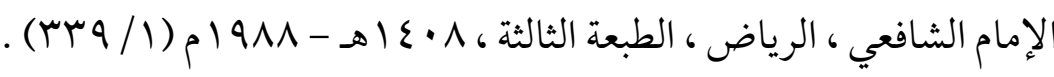


(TrI)

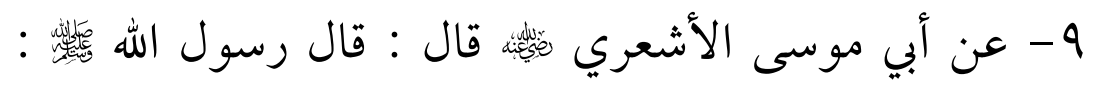

((قال لقحان لابنه وهو يعظه : يا بني إياك والتقنع ، فإنها خخوفة بالليل

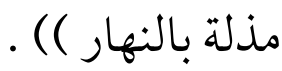

\section{: تخريج الحلديث}

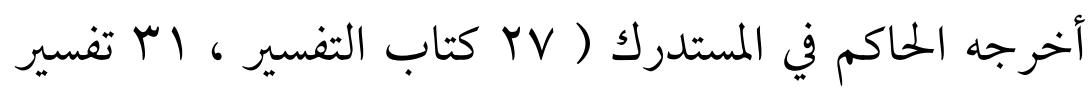

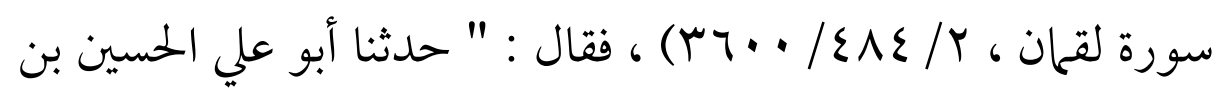

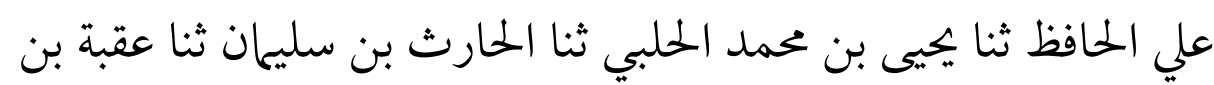

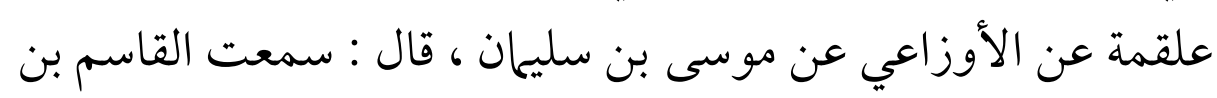

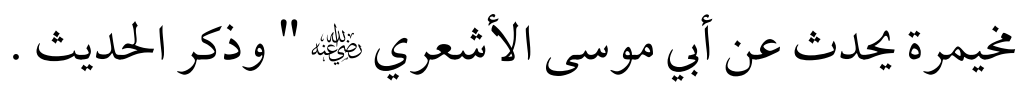

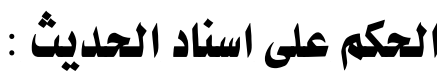

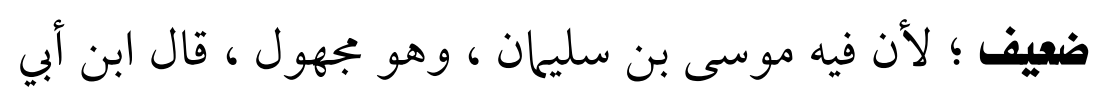

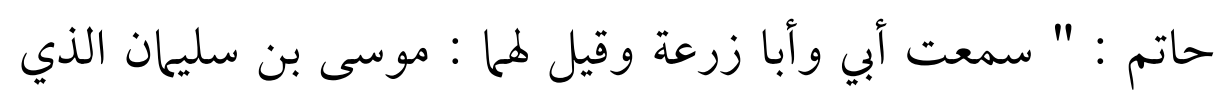

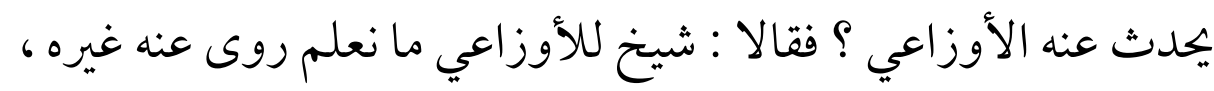

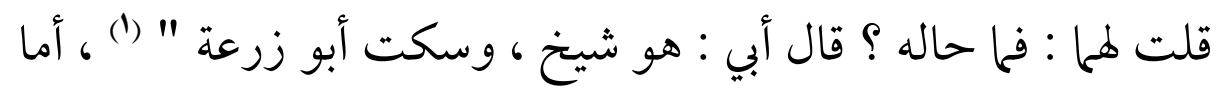

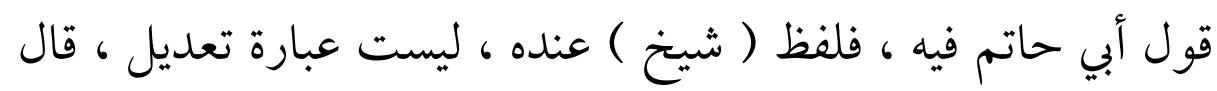

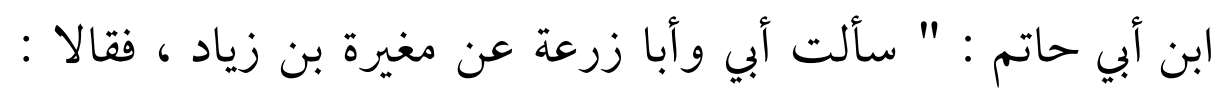

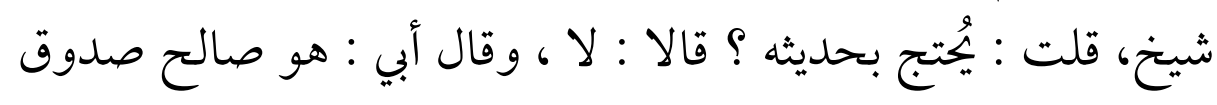

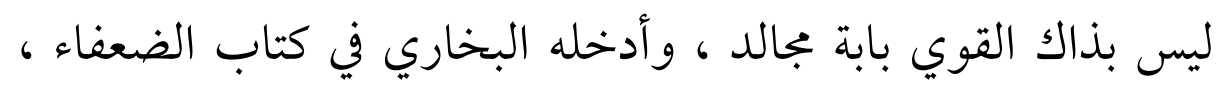




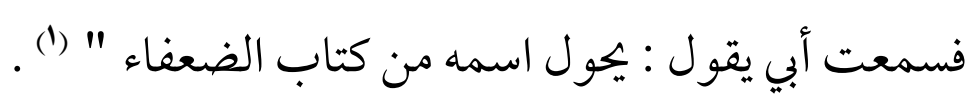

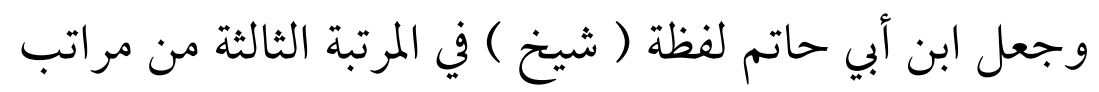

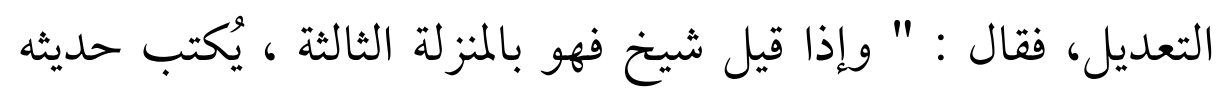

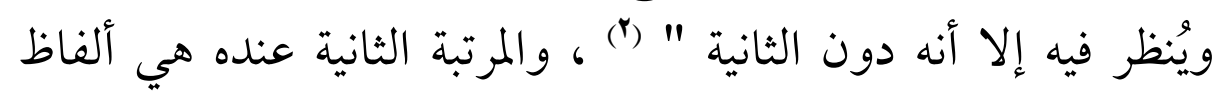

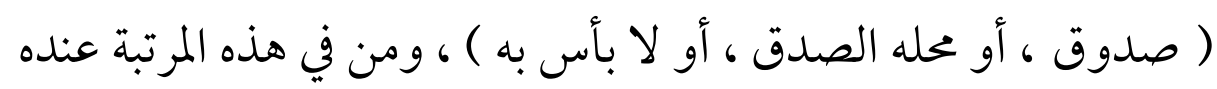

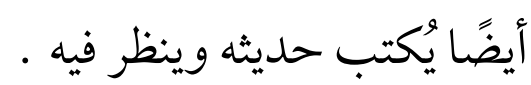
وقال ابن القطان الفاسي : " فأما قول أبي حاتم فيه : ( شيخ ) فليس بتعريف بشيء من حاله ، إلا أنه مقل ليس من أهل العلم ، وإنها

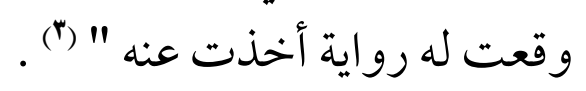
قال الذهبي في ترجمة العباس بن الفضل العدني : " سمع منه أبو

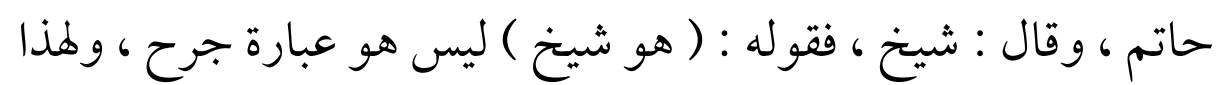

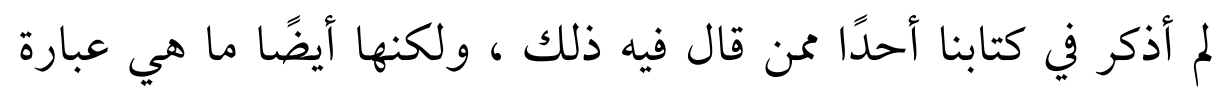
توثيق ، وبالاستقراء يلوح لك أنه ليس بحجة ، ومن ذلك قوله :

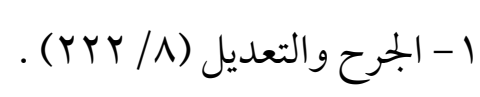

$$
\begin{aligned}
& \text { r- الجرح والتعديل (r/ }
\end{aligned}
$$

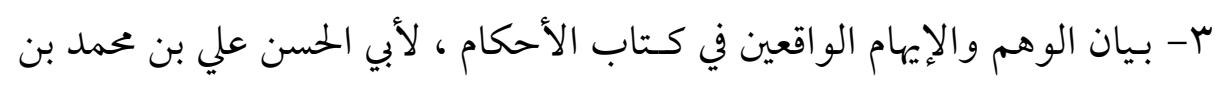

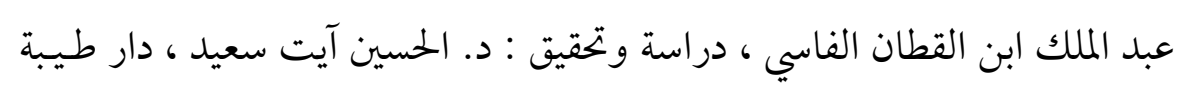

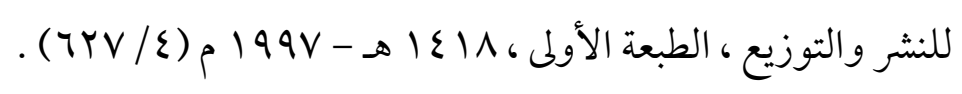


(TrY)

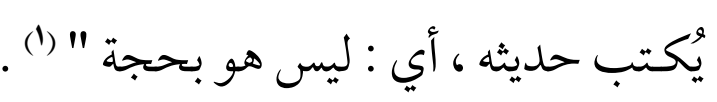

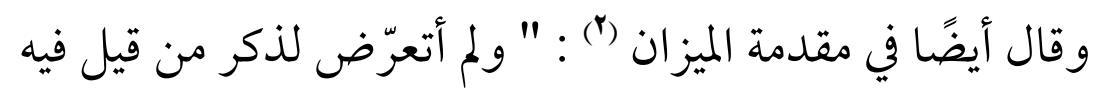

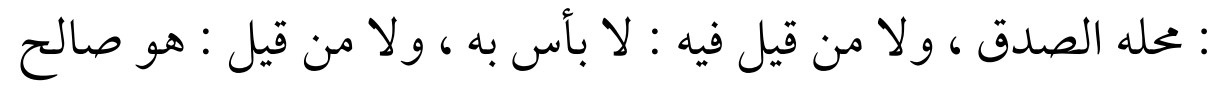

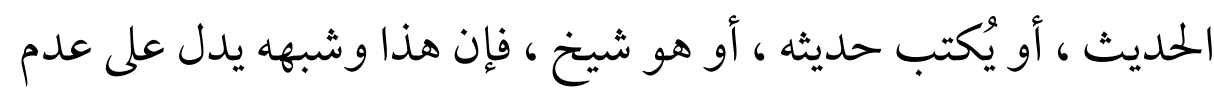

$$
\text { الضعف المطلق " . }
$$

وقال ابن حجر عن موسى بن سلي/ان : " مقبول " (") ، وقد

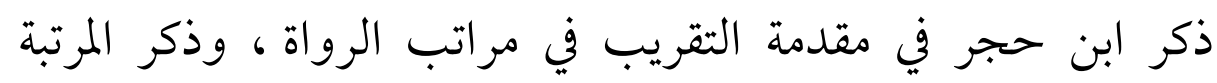

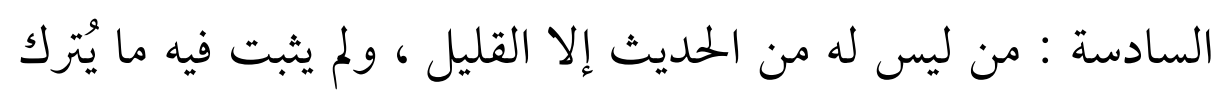

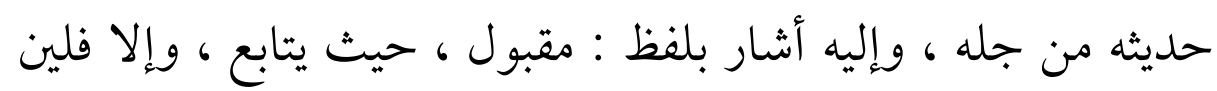

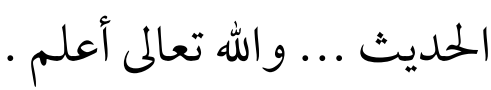

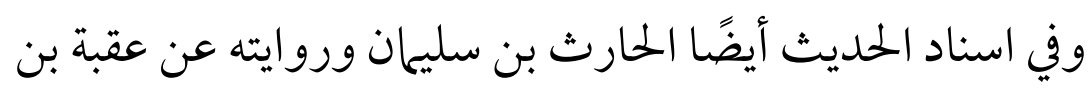

علقمة ضعيفة ، قال ابن عدي : " وللحارث بن سليمان عن عقبة

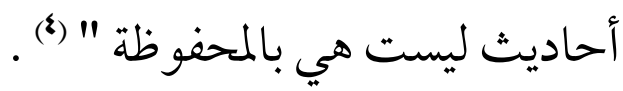

$$
\begin{aligned}
& \text { 1 - ميزان الاعتدال (ع/ مه ). } \\
& \text { r - المرجع نفسه . }
\end{aligned}
$$

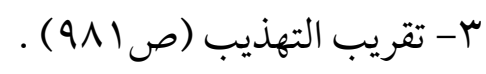

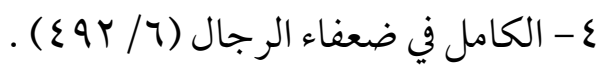




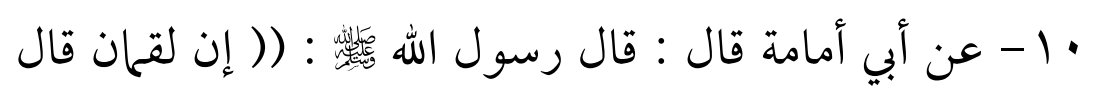

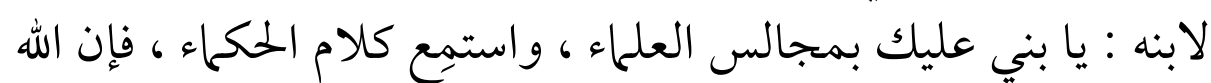

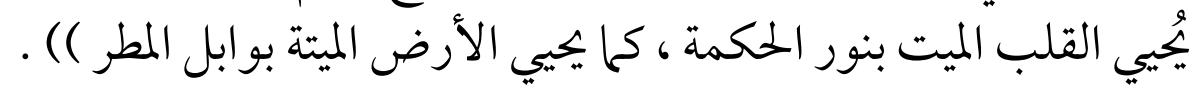

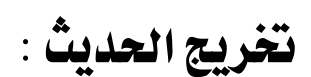

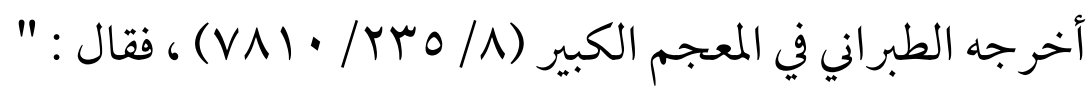

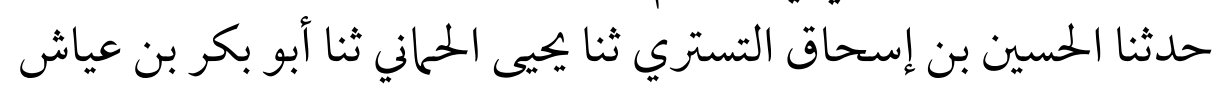

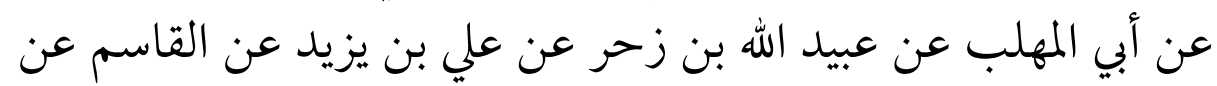

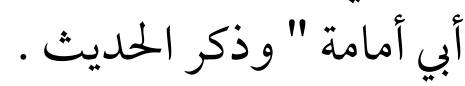

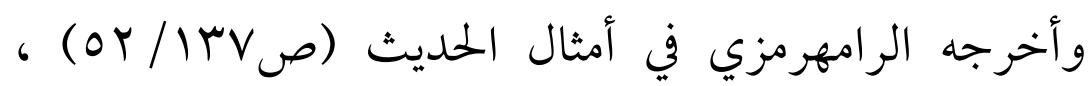

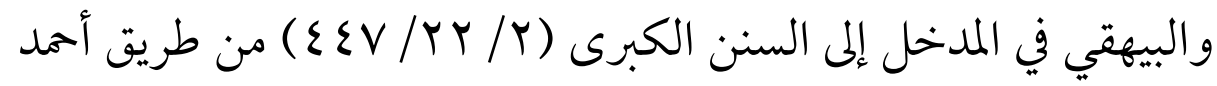
بن يونس به . كلاهما : ( يحيى الحماني ، وأحمد بن يونس ) عن أبي بكر بن عياش به .

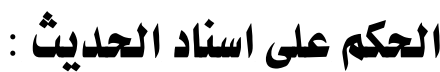

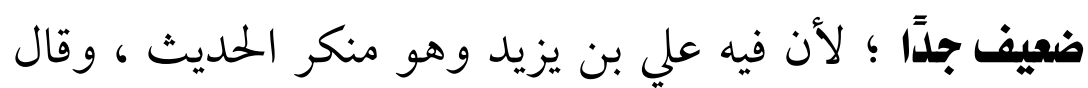

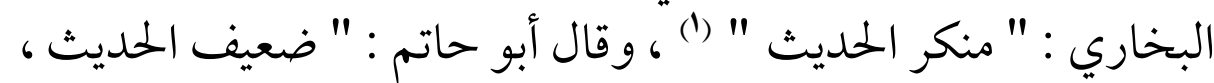

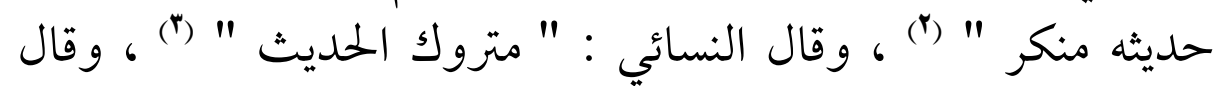

$$
\begin{aligned}
& 1 \text { - التاريخ الكبير (T/ 1 • (Y) . }
\end{aligned}
$$

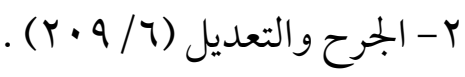

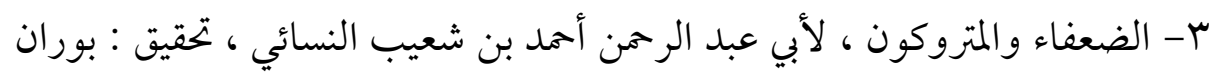

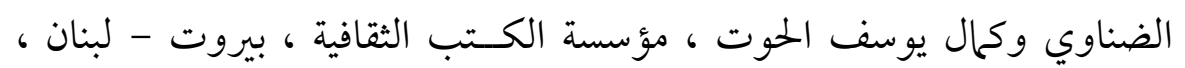

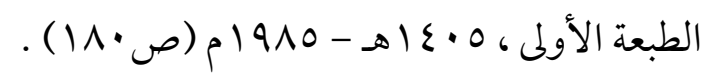


الدراقطني : " متروك " (ا) وضعفه جماعة ، وفيه أيضًا أبو المهلب مطرح

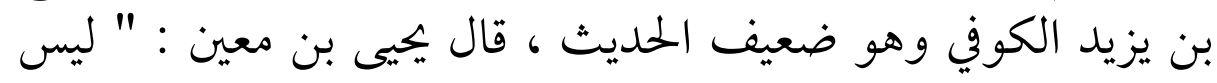

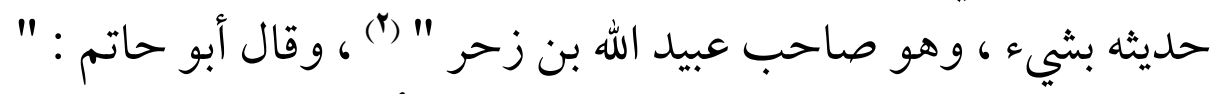

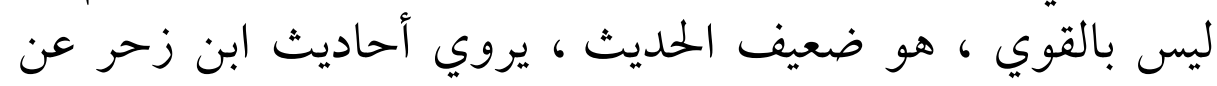

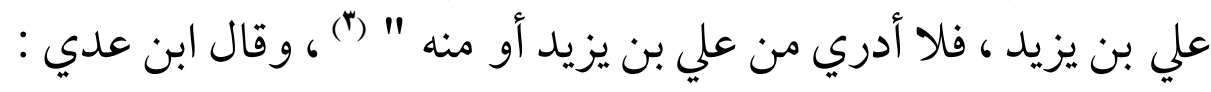

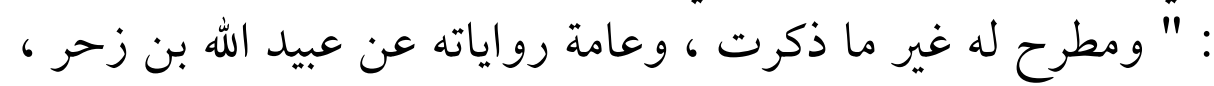

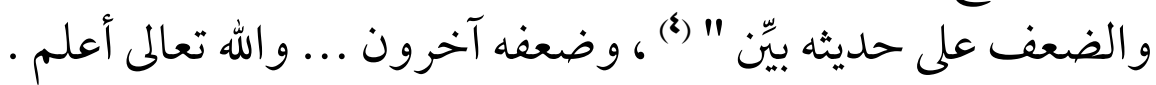

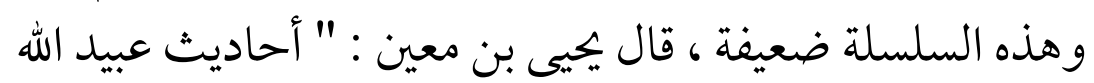

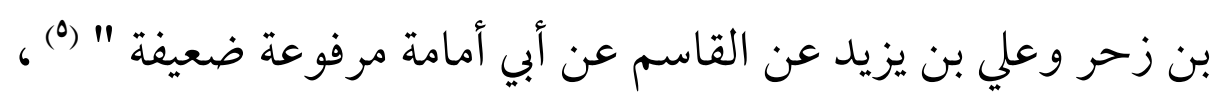

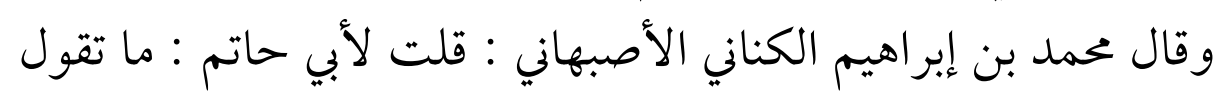

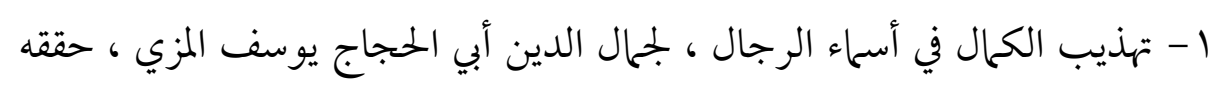

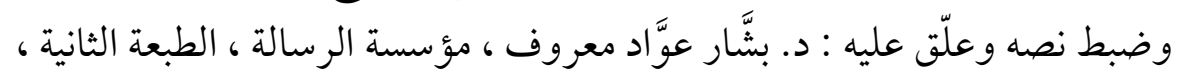

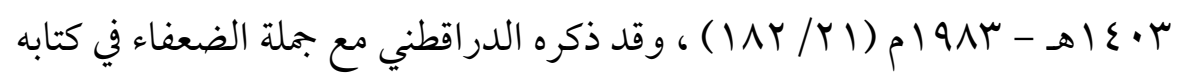

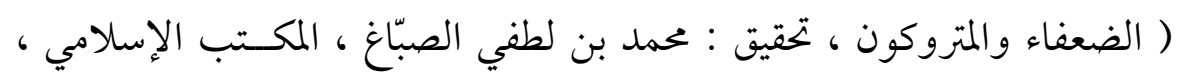

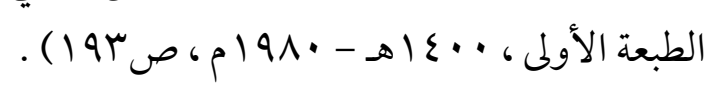

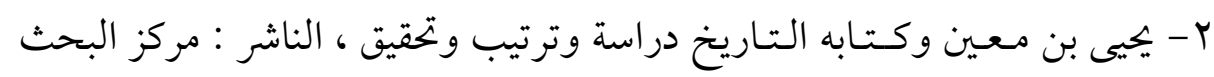

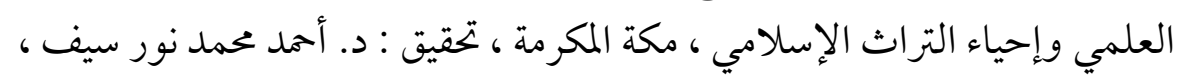

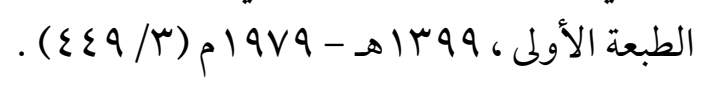

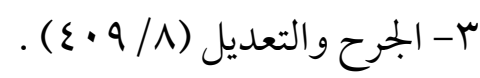

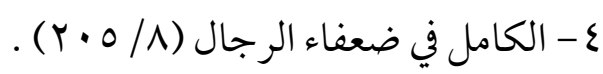

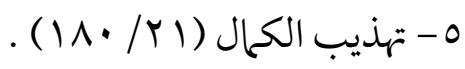


في أحاديث علي بن يزيد عن القاسم عن أبي أمامة ؟ قال : " ليست قوية، هي ضعاف " (1) ... و واله أعلم .

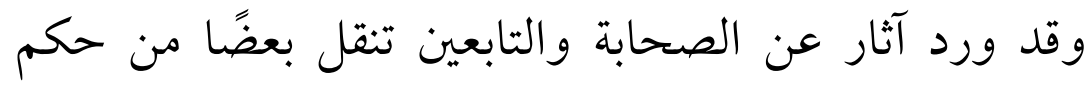

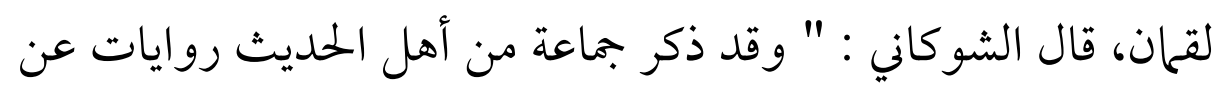

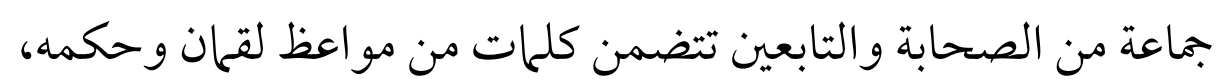

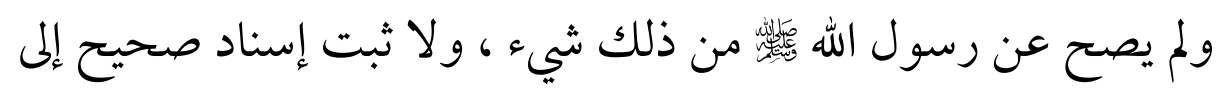

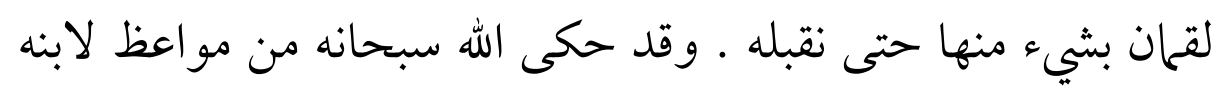

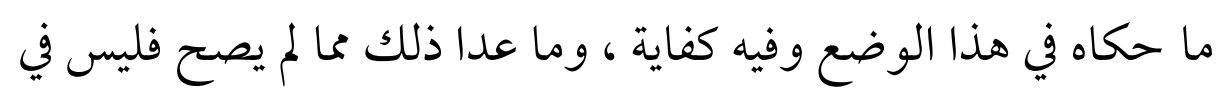

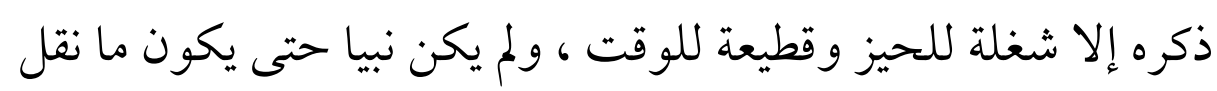

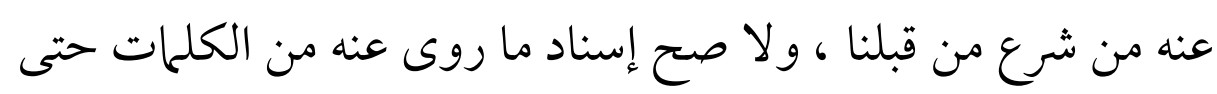

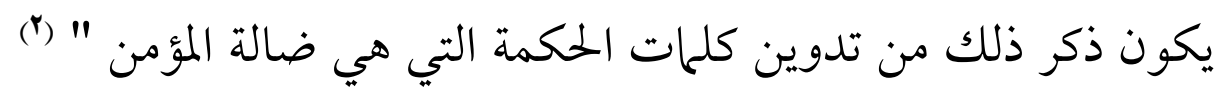

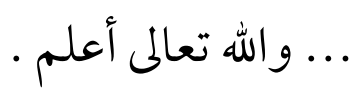

\footnotetext{
1 - 1 - المرجع نفسه .

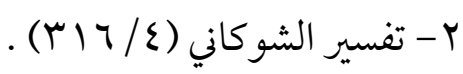




\section{الخاتهـة}

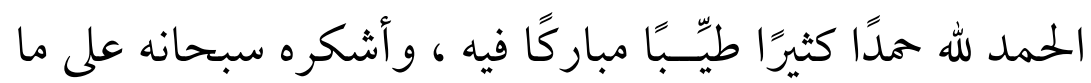

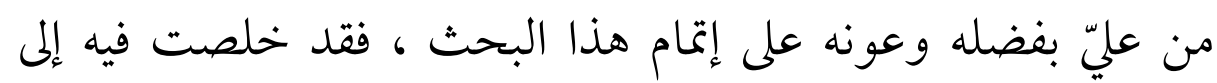

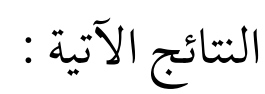

\section{أولاً : أهم نتائج اللدراسة في التمهيد ما يلي :}

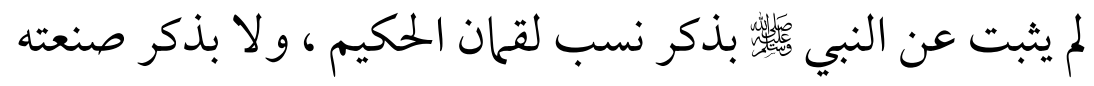
لكن هناك أقوال لبعض التابعين في ذلك ، وليس هناك دليل قطعي في ني لني ذلك.

\section{ثانيًا : أهم تتائج دراسة الأحاديث المرفوعة الواردة في لقماز :}

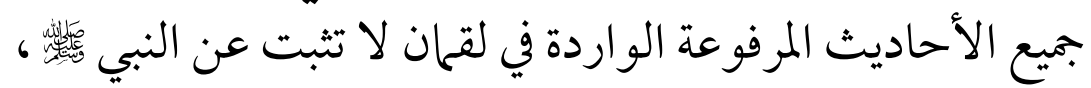

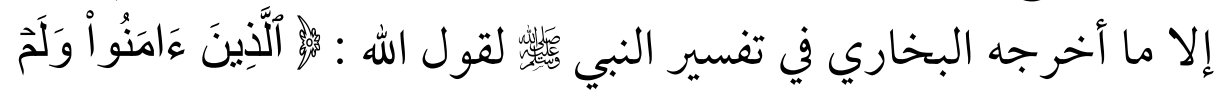

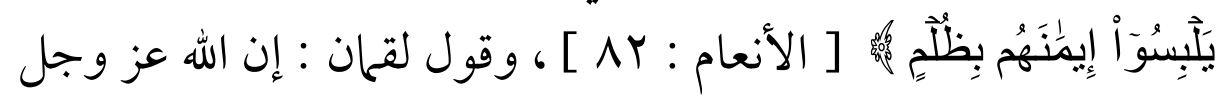

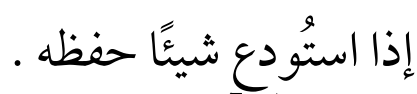

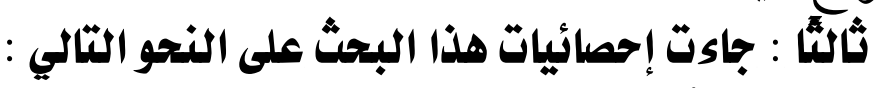

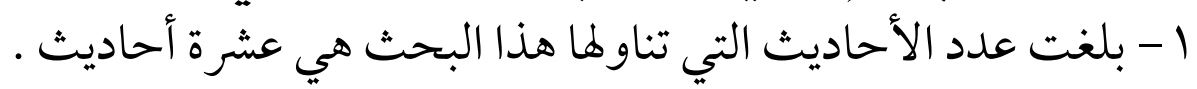

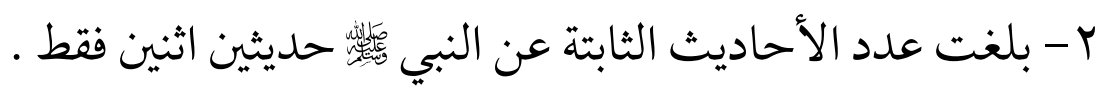

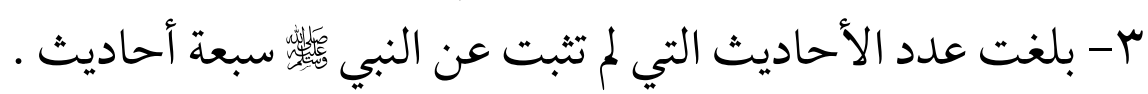

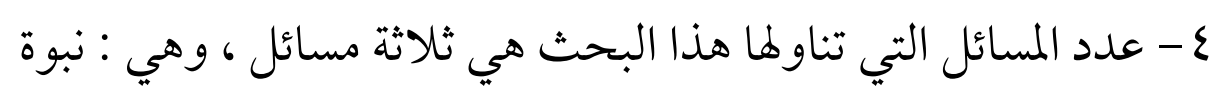
وموطن لقمان و العصر الذي عاش فيه . 
(TYA)

الأحاديث المرفوعة الواردة في لتقمان

وفي ختام هذا العمل أحمد الله الذي بنعمته تتم الصالحات ،

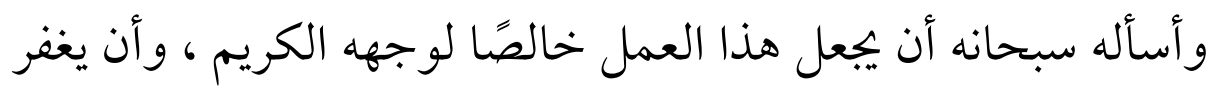

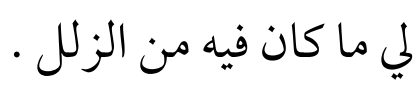

سبحانك اللهم وبحمدك ، أشهد أن لا إله إلا أنت ، أستغفرك أله

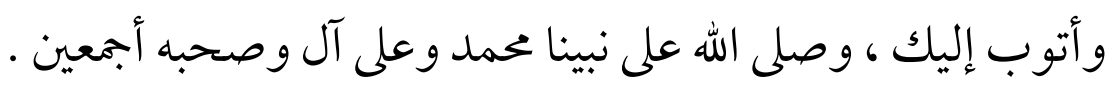


(7rq)

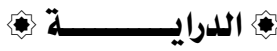

$$
\begin{aligned}
& \text { فهرس المصادر والمراجع : } \\
& \text { ( مرتبة على حسب حروف المعجم ) : } \\
& 1 \text { - القرآن الكريه. }
\end{aligned}
$$

ץ - آثار البلاد وأخبار العباد ، لزكرياء بن محمد بن محمود القزويني ، دار

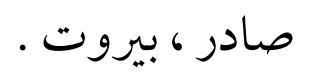

ب- الإرشاد في معرفة علماء الحلديث ( من تجزئة السّّلفي ) ، لأبي يعلى الخليل بن عبد الله بن أحمد بن الخليل الخليلي القزويني ، دراسة وتحقيق وتخريج : د. محمد سعيد بن عمر إدريس ، مكتبة الرشد ، الرياض ، الطبعة الأولى ، 9 • ع 1 هـ - 1919 م م . ع - الإصابة في تميـيـز الصحابة ، للحافظ أبي الفضل أحمد بن علي بن حجر العسقلاني ، تحقيق : د. عبد الله بن عبد المحسن التركي ، مركز هجر للبحوث والدراسات العربية والإسلامية ، الطبعة

$$
\text { الأولى }
$$

- أمثال الحديث ، لأبي محمد الحسن بن عبد الرحمن بن خلال الرامهرمزي ، تحقيق : د. عبد العلى عبد الحميد الأعظمي ، لكئل 
(Tr.)

الأحاديث المرفوعة الواردة في لثمان

الدار السلفية ، بومباي - الهند ، الطبعة الأولى ، ع •ع اهـ-

- $191 \mu$

7- البلاية والنهاية ، لعماد الدين أبي الفاء إسماعيل بن عمر بن كثير

القرشي الدمشقي ، تحقيق : د. عبد الله بن عبد المحسن التركي

بالتعاون مع مركز البحوث والدراسات العربية والإسلامية

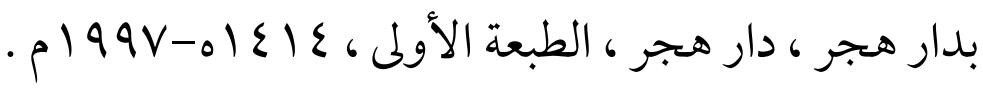

V- بـيان الوهم والإيهام الواقعين في كـتاب الأحكام ، لأبي الحسن علي

بن محمد بن عبد الملك ابن القطان الفاسي ، دراسة وتحقيق : د.

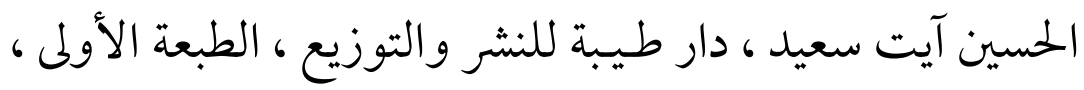

$$
\text { - 199V-ه 1 1 م11 }
$$

^- التاريخ الكبير ، لأبي عبد الله إسماعيل بن إبراهيم الجعفي البخاري

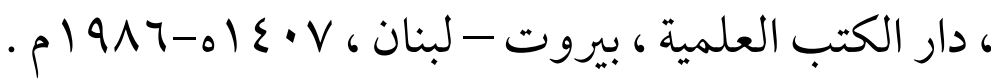

9- تاريخ مدينة دمشق وذكر فضلها وتسمية من حلها من الأماثل أو

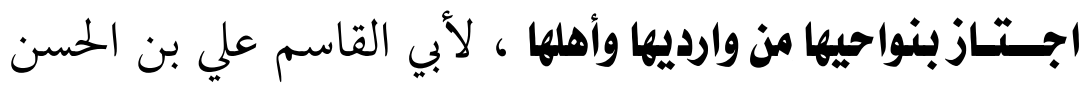

بن هبة الله بن عبد الله الشافعي المعروف بابن عساكر ، دراسة 
(7rl)

وتحقيق : محب الدين أبي سعيد عمر غرامة العمروي ، دار الفكر

$$
\text { - 1990-ه1:10، }
$$

• 1 - تاريخ مدينة السلام وأخبار محدثيها وذكر قطّانها العلماء من غير أهلها ووارديها ، لأبي بكر أحمد بن علي بن ثابت إئ الخطيب البغدادي ، تحقيق : د. بشار عواد معروف ، دار الغرب

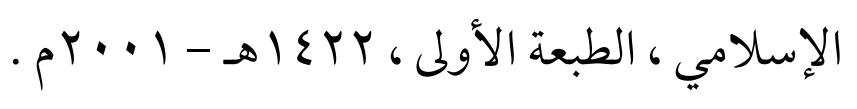

1 ا - تفسير القرآذ ، لعبد الرزاق بن همام الصنعاني ، تحقيق : د. مصطفى مسلم محمد ، مكتبة الرشد ، الرياض ، الطبعة الأولى ،

$$
\text { . } 1919-01 \leqslant 1 .
$$

ץ ا - تفسير القرآن العظيه ، لأبي الفداء إسماعيل بن عمر بن كـثير القرشي الدمشقي ، تحقيق : سامي بن محمد السلامة ، دار طيبة للنشر والتوزيع ، الرياض ، الطبعة الثانية ، · بع اهـ - 999 ام

با - تقريب التهذذيب ، لأحمد بن علي بن حجر العسقلاني ، حققه وعلق عليه ووضحه وأضاف إليه : أبو الأشبال صغير أحمد 
شاغف الباكستاني ، دار العاصمة للنشر والتوزيع ، الطبعة

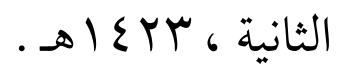

ع ا - تهذيب الكمال في أسماء الرجال ، لجحال الدين أبي الحجاج يوسف المزي ، حققه وضبط نصه وعلّق عليه : د. بشَّار عوَّاد معروف ،

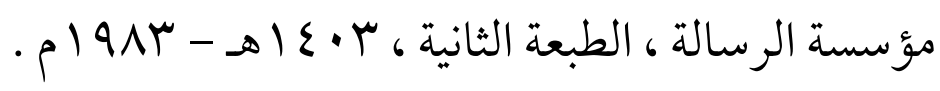
1 - الـتيسيـر بشرح الجامع الصفير ، لزين الدين عبد الرؤوف المناوي ، الناشر : مكــتبة الإمام الشافعي ، الرياض ، الطبعة

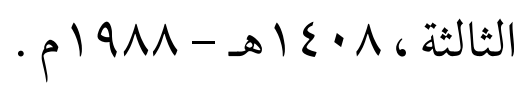
17 - الجامع المسند الصحيح المختـصر من أمور رسول اللّه وأيامه ، لأبي عبد الله محمد بن إسماعيل بن إبراهيم بن المغيرة المئ

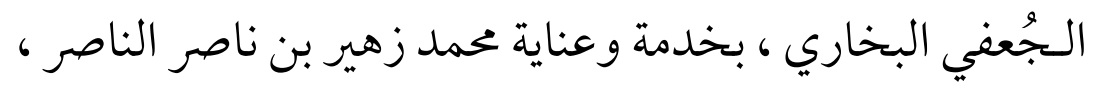

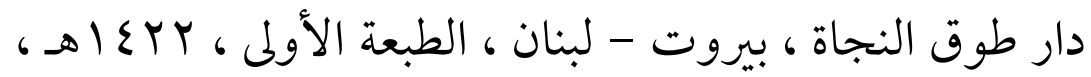
وهي نسخة مصورة من المطبعة الأميرية ببولاق . IV - جامع البـيان عن تأويل آي القرآن ( تفسير الطبري ) ، لأبي جعفر محمد بن جرير الطبري ، تحقيق : د. عبد الله بن عبد المحسن التركي بالتعاون مع مركز البحوث والدراسات العربية 
والإسلامية بدار هجر ، دار هجر للطباعة والنشر والتوزيع

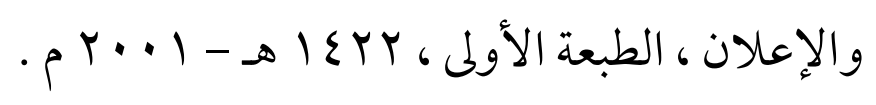

11 - الجامع لأحكام الـقرآن والمبيّئ ما تضمنه من السنة وآي القرآن ، لأبي عبد الله محمد بن أحمد بن أبي بكر القرطبي ، تحقيق : د. عبد الله بن عبد المحسن التركي وآخرون ، مؤسسة الرسالة ، الطبعة

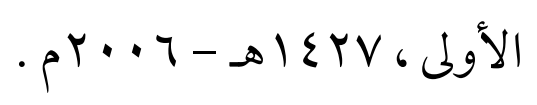

19 - الجامع لشعب الإيهان ، لأبي بكر أحمد بن الحسين البيهقي ، تحقيق :

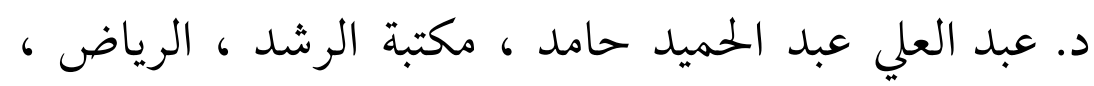

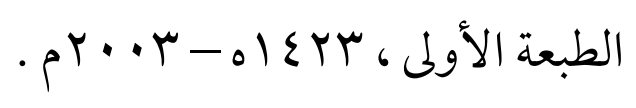

• · - الجرح والتـعلديل ، لأبي محمد عبد الرحمن الرازي ابن أبي حاتم،

اعتنى بـتصحيحه والتعليق عليه : الشيخ عبد الرحمن بن يميى

المعلمي اليماني ، الناشر : الفاروق الحديثه للطباعة والنشر ك. نسخة مصورة من طبعة بجلس دائرة المعارف العثمانية ، حيدر

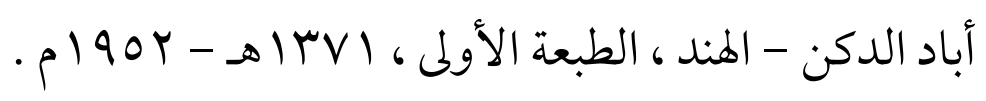


ا Y- جمهرة اللفة ، لأبي بكر محمد بن الحسين بن دريد الأزدي ، تحقيق ، رمزي منير بعلبكي ، دار العلم للملايين ، بيروت - لبنان :

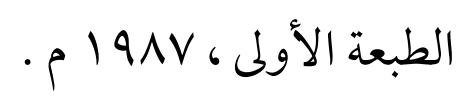

Y Y - الدر المنثور في التفسير بالمأثور، لجلال الدين السيوطي ، تحقيق : د. عبد الله بن عبد المحسن التركي بالتعاون مع مركز هجر للبحوث و الدراسات العربية والإسلامية ، دار هجر ، القاهرة ،

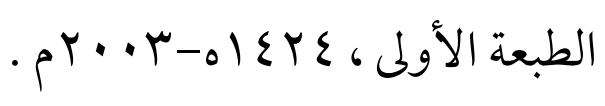

ץץ- دلائل السبوة ومعرفة أحوال صاحب الشريعة ، لأبي بكر أحمد بن الحسين البيهقي ، وثَّق أصوله وخرج حديثه وعلق عليه : د. عبد المعطي قلعجي ، دار الكستب العلمية ، بيروت - لبنان ،

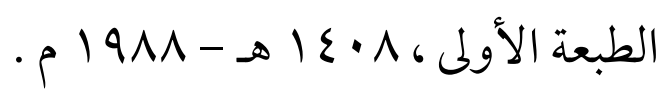

ع - الزهل ، لأبي عبد الله أحمد بن محمد بن حنبل الشيباني ، دار الكتب

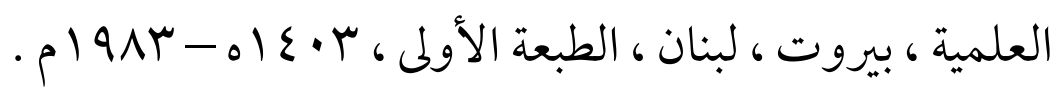


(7ro)

O - سلسلة الأحاديث الضعيفة والموضوعة وأثرها السيك في الأمة ،

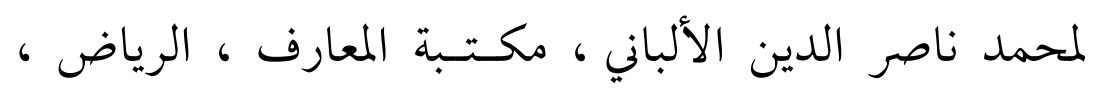

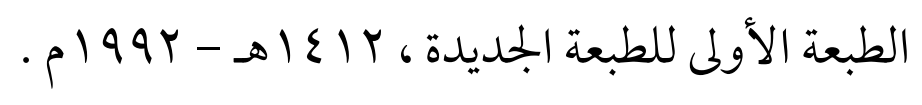

Tr - السنز الكبرى ، لأبي عبد الرحمن أحمد بن شعيب النسائي ، تحقيق :

حسن عبد المنعم شلبي ، أشرف عليه : شعيب الأرنؤوط ،

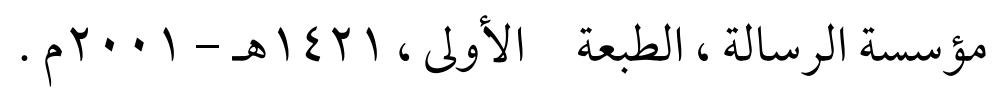

YV الأبياري وعبد الحفيظ شلبي ·

^r - الضعفاء والمـتروكون ، لأبي عبد الرحمن أحمد بن شعيب النسائي ، تحقيق : بوران الضناوي وكمال يوسف الحوت ، مؤسسة الكـتب الثقافية ، بيروت - لبنان ، الطبعة الأولى ، 0 • ع اهـ -

$$
\text { - p } 1910
$$

q - الضعفاء والمتروكون ، لعلي بن عمر بن أحمد الدارقطني ، تحقيق : محمد بن لطفي الصبّاغ ، المكـتب الإسلامي ، الطبعة الأولى ،

$$
\text { - } 191 \cdot-ه 1 \varepsilon \cdots
$$


• ץ- الطبقات الكبير ، لمحمد بن سعد بن منيع الزهري ، تحقيق : د. علي محمد عمر ، الناشر : مكستبة الخانجي ، القاهرة - مصر . اب- العبر في خبر من غبر ، للحافظ الذهبي ، تحقيق : محمد السعيد بن بسيوني زغلول ، دار الكتب العلمية ، بيروت - لبنان ، الطبعة

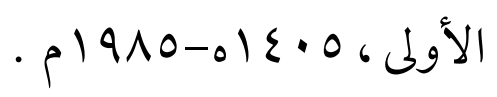

rr- غريب الحديث ، لأبي إسحاق إبراهيم بن إسحاق الحربي ، تحقيق ودراسة : د. سليمان بن إبراهيم بن محمد العايد ، دار المدني للطباعة والنشر والتوزيع ، الطبعة الأولى ، 0 • ع اهـ - 1910 ام

سب- قتح القدير الجامع بين فني الرواية والدراية من علم التفسير ، لمحمد بن علي بن محمد الشوكاني ، تحقيق : د. عبد الرحمن عميرة

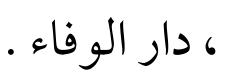

ع ب- الفوائد المجموعة في الأحاديث الموضوعة ، لمحمد بن علي الشوكاني ، تحقيق : العلامة عبد الرحمن المعلمي ، المكتب الإسلامي ،

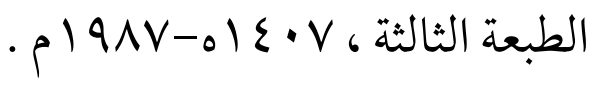


هـ- قصص الأنبياء المسمى بالعرائس ، لأبي إسحاق أحمد بن محمد بن

إبراهيم النيسابوري الثعلبي ، مكتبة الجمهورية العربية ، مصر ،

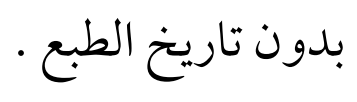

جس- الكامل في ضعفاء الرجال ، لأبي أحمد عبد الله بن عَدي الجرجاني ، تحقيق وتعليق : عادل أحمد عبد الموجود وعلي محمد معوّض وشارك في تحقيقه أ.د. عبد الفتاح أبو سنّة ، دار الكـــب

$$
\text { العلمية ، بيروت - لبنان . }
$$

rV القاسم محمود بن عمر الزخشري ، تحقيق وتعليق : عادل أحمد عبد الموجود وعلي محمد معوض ، مكتبة العبيكان ، الرياض ،

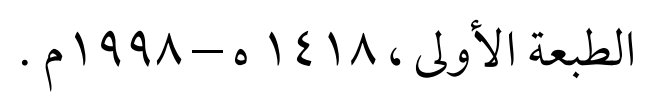

مب - اللآلئ المصنوعة في الأحاديث الموضوعة ، لجلال الدين السيوطي ،

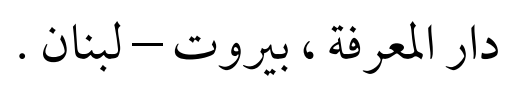

هץ- لسان العرب ، لأبي الفضل جمال الدين ابن منظور الأنصاري الإفريقي ، دار صادر ، بيروت ، الطبعة الثالثة ، عالعاهـ. 
• ع - المجروحين من المحلثين ، لابن حبان ، تحقيق : حمدي عبد المجيد

السلفي ، دار الصميعي للنشر والتوزيع ، الطبعة الأولى ،

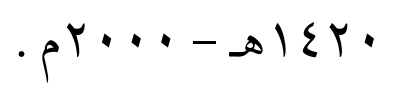

اع - المحكم والمحيط الأعظم ، لأبي الحسن علي بن إسماعيل بن سيده المرسي ، تحقيق : د. عبد الحميد هنداوي ، دار الكــتب العلمية

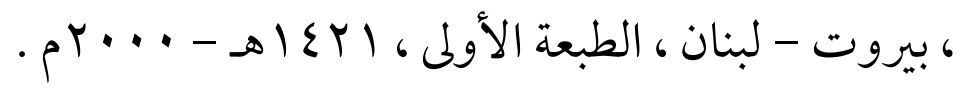

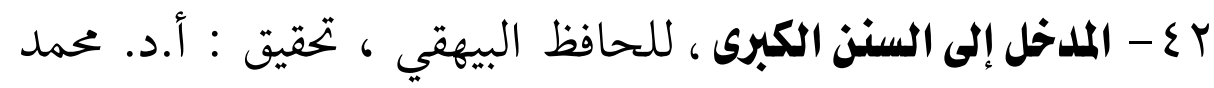

ضياء الرحمن الأعظمي ، أضواء السلف ، الطبعة الثانية ،

$$
.01 \leqslant Y \text {. }
$$

بح - المسالك والممالك ، لأبي عبيد عبد الله بن عبد العزيز بن محمد

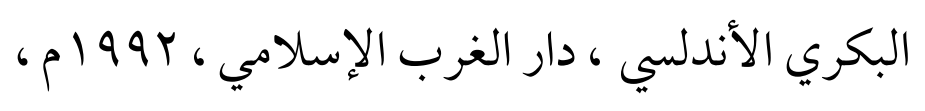

ع - المستـلدرك على الصحيحيز ، لأبي عبد الله الحاكم النيسابوري ،

طبعة متضمنة اتثقادات الذهبي ، وبذيله تتبع أوهام الحاكم التي

سكت عليها الذهبي ، لأبي عبد الرحمن مقبل بن هادي الوادعي ، 


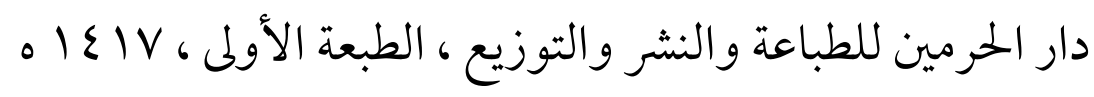

$$
\text { - } 199 \mathrm{~V}-
$$

ع - مسند الإمام أحمل بن حسنبل ، حققه وخرج أحاديثه وعلق عليه : شعيب الأرنؤوط وعادل مُرشد ، مؤسسة الرسالة ، الطبعة

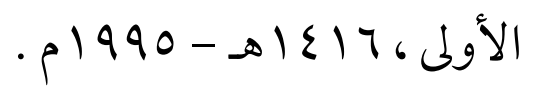

حع - المصنف ، لأبي بكر عبد الله بن محمد بن أبي شيبة العبسي الكوفي ،

تحقيق : محمد عوامة ، شركة دار القبلة ، الطبعة الأولى ،

$$
\cdot 6 r \cdot T-\Delta) \& r V
$$

ع V عكاشة ، دار المعارف ، القاهرة ، الطبعة الرابعة .

^乏 - المعجم الكبير ، لأبي القاسم سليمان بن أحمد الطبراني ، حققه وخرج أحاديثه : حمدي عبد المجيد السلفي ، مكــتبة ابن تيمية

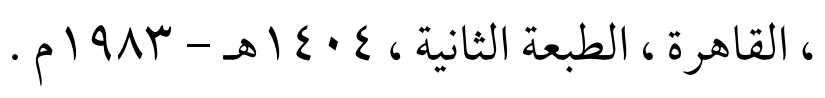

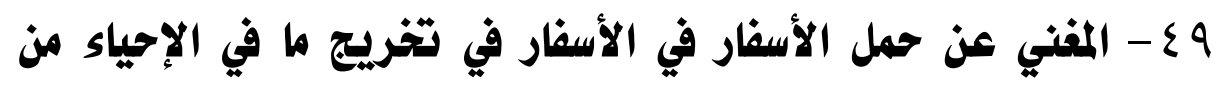

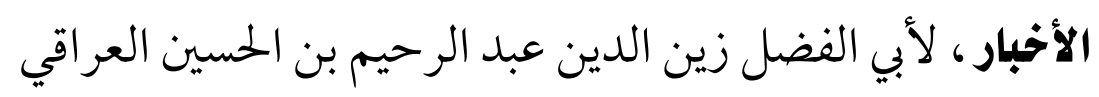


، اعتنى به : أبو محمد أشرف بن عبد المقصود ، مكــتبة دار طبرية ، الرياض ، الطبعة الأولى، 10 ع (هـ - 1990 1م . • - المنار المنيف في الصحيح والضعيف ، لأبي عبد الله محمد بن أبي بكر بن أيوب ابن القيم الجوزية ، تحقيق : يجيى عبد الله الثثالي ، دار

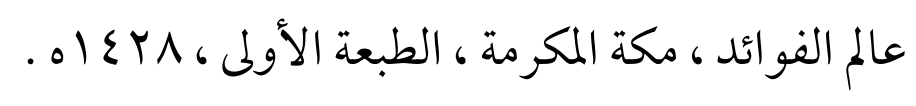
ا 0 - المنستخب من مسند عبل بن حُميلد ، تحقيق وتعليق : أبي عبد الله مصطفى بن العدوي ، دار بلنسية للنشر والتوزيع ، الرياض ،

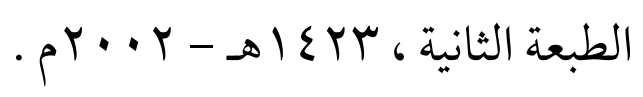

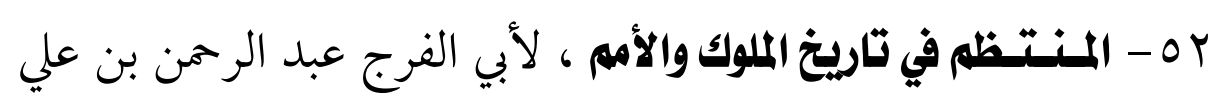
بن محمد ابن الجوزي ، دراسة وتحقيق : محمد عبد القادر عطا ومصطفى عبد القادر عطا ، دار الكستب العلمية ، بيروت -

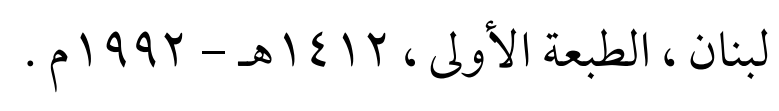
به - ميزان الاعـــدال في نقد الرجال ، لشمس الدين محمد بن أحمد الذهبي ، ويليه ذيل ميزان الاعتدال ، لأبي الفضل عبد الرحيم بن الحسين العراقي ، دراسة وتحقيق : علي محمد معوض وعادل 
(7₹1)

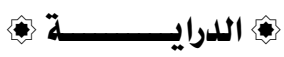

أحمد عبد الموجود ، شارك في تحقيقه : أ.د. عبد الفتاح أبو سنّة ،

دار الكـتب العلمية ، بيروت - لبنان ، الطبعة الأولى ،

$$
\text { . } 1990-ه 1 \leqslant 17
$$

ع - النكت والعيوز تفسير الماوردي ، لأبي الحسن علي بن محمد بن

حبيب الماوردي البصري ، راجعه وعلق عليه : السيد بن عبد

المقصود بن عبد الرحيم ، دار الكتب العلمية ، بيروت - لبنان .

0 - الوسيط في تفسير القرآن المجيد ، لأبي الحسن علي بن أحمد

الواحدي النيسابوري ، تحقيق : عادل أحمد عبد الموجود

وآخرون ، دار الكتب العلمية ، بيروت - لبنان ، الطبعة الأولى ،

$$
\text { p } 199 \varepsilon-01 \leqslant 10
$$

ك- بحيى بن مـسين وكستابه الستاريخ دراسة وترتيب وتحقيق ،

الناشر : مركز البحث العلمي وإحياء التراث الإسلامي ، مكة

المكرمة ، تحقيق : د. أحمد محمد نور سيف ، الطبعة الأولى ،

$\cdot p 19 \vee q-\Delta 1199$ 